\title{
Endophytic Colletotrichum species from Dendrobium spp. in China and Northern Thailand
}

\author{
Xiaoya Ma ${ }^{1,2,3}$, Sureeporn Nontachaiyapoom ${ }^{2,3}$, Ruvishika S. Jayawardena ${ }^{2,3}$, \\ Kevin D. Hyde ${ }^{2,3}$, Eleni Gentekaki ${ }^{3}$, Sixuan Zhou ${ }^{1,4}$, Yixin Qian', \\ Tingchi Wen', Jichuan Kang'
}

I Engineering and Research Center for Southwest Biopharmaceutical Resource of National Education Ministry of China, Guizhou University, Guiyang 550025, Guizhou Province, People's Republic of China 2 Center of Excellence in Fungal Research, Mae Fah Luang University, Chiang Rai 57100, Thailand 3 School of Science, Mae Fah Luang University, Chiang Rai 57100, Thailand 4 Guizhou Institute of Animal Husbandry and Veterinary, Guiyang, Guizhou province, 550005, People's Republic of China

Corresponding author: Jichuan Kang (jckang@gzu.edu.cn)

Academic editor: Andrew Miller | Received 16 March 2018 | Accepted 3 November 2018 | Published 4 December 2018

Citation: Ma X, Nontachaiyapoom S, Jayawardena RS, Hyde KD, Gentekaki E, Zhou S, Qian Y, Wen T, Kang J (2018) Endophytic Colletotrichum species from Dendrobium spp. in China and Northern Thailandle. MycoKeys 43: 23-57. https://doi.org/10.3897/mycokeys.43.25081

\begin{abstract}
Species of Colletotrichum are commonly found in many plant hosts as pathogens, endophytes and occasionally saprobes. Twenty-two Colletotrichum strains were isolated from three Dendrobium species $D$. cariniferum, $D$. catenatum and $D$. harveyanum, as well as three unidentified species. The taxa were identified using morphological characterisation and phylogenetic analyses of ITS, GAPDH, ACT and $ß$-tubulin sequence data. This is the first time to identify endophytic fungi from Dendrobium orchids using the above method. The known species, Colletotrichum boninense, C. camelliae-japonicae, C. fructicola, C. jiangxiense and C. orchidophilum were identified as fungal endophytes of Dendrobium spp., along with the new species, C. cariniferi, C. chiangraiense, C. doitungense, C. parallelophorum and C. watphraense, which are introduced in this paper. One strain is recorded as an unidentified species. Corn meal agar is recommended as a good sporulation medium for Colletotrichum species. This is the first report of fungal endophytes associated with Dendrobium cariniferum and D. harveyanum. Colletotrichum camelliae-japonicae, C. jiangxiense, and C. orchidophilum are new host records for Thailand.
\end{abstract}

\section{Keywords}

Colletotrichum, Dendrobium, Endophytic fungi, multi-loci, new species

Copyright Xiaoya Ma et al. This is an open access article distributed under the terms of the Creative Commons Attribution License (CC BY 4.0), which permits unrestricted use, distribution, and reproduction in any medium, provided the original author and source are credited. 


\section{Introduction}

Colletotrichum is the sole genus in family Glomerellaceae (Glomerellales) (Maharachchikumbura et al. 2015, 2016; Jayawardena et al. 2016b; Hongsanan et al. 2017). Presently, there are 193 accepted Colletotrichum species in eleven species complexes and 23 accepted singleton species (Hyde et al. 2014; Jayawardena et al. 2016a). Colletotrichum species has been listed as one of the top ten fungal pathogenic genera in molecular plant pathology based on scientific/economic importance (Dean et al. 2012). Anthracnose caused by Colletotrichum species can be a devastating disease in many economically important crops, including fruit crops, vegetables, cassava, sorghum, as well as ornamental plant such as orchids (Prusky and Plumbley 1992; Hyde et al. 2009a, b; Cannon et al. 2012; Dean et al. 2012; Jadrane et al. 2012; Jayawardena et al. 2016a; Diao et al. 2017). Many pathogenic Colletotrichum species that adopt biotrophic life strategies are present as symptomless endophytes in living plant tissues (Photita et al. 2004), although a large number of non-pathogenic species also occur as endophytes (e.g. Mendgen and Matthias 2002; Lu et al. 2004; Rojas et al. 2010; Cannon et al. 2012; Kleemann et al. 2012). Interestingly, experiments of Redman et al. (2001) showed that pathogenic Colletotrichum species could express mutualistic lifestyles in plants not known to be hosts and conferred disease resistance, drought tolerance, and/or growth enhancement to the host plants. Even though the diversity of Colletotrichum species associated with cultivated plant hosts have extensively been studied (Yang et al. 2009), a very limited number of studies has been conducted on Colletotrichum species from non-cultivated plants in natural and semi-natural habitats (Cannon et al. 2012).

Dendrobium SW. is the second largest genus in Orchidaceae (The Plant List 2013). Most Dendrobium species/hybrids are important ornamental/floricultural crops, but some species within this genus also possess medicinal values (Xu et al. 1995; Ng et al. 2012). Many Dendrobium orchids have been listed as Chinese medicinal herbs and are used for the treatments of atrophic gastritis, diabetes, faucitis, fever, red tongue, and/ or thirsty (Ping et al. 2003; Bulpitt et al. 2007; Xing et al. 2011; Xia et al. 2012; Xu et al. 2014). Moreover, some Dendrobium orchids including D. catenatum Lindl. (widely known as $D$. officinale Kimura \& Migo) have been listed as critically endangered species by the International Union for Conservation of Nature (IUCN) (www.iucnredlist.org). Due to their significance, Dendrobium orchids have been the subject of many studies including the diversity of endophytic fungi (Ma et al. 2015). However, only a limited number of studies on endophytic Colletotrichum in Dendrobium species have been reported and the number of Dendrobium species included in these studies are very few (Yuan et al. 2009; Yang et al. 2011; Mangunwardoyo et al. 2011; Chen et al. 2012; Noireung et al. 2012; Tao et al. 2013). In the present study, we investigated the diversity of endophytic Colletotrichum in five Dendrobium orchid species collected from a mountain (at an elevation of 1,300-1,400 m) close to the Thailand-Myanmar border and D. catenatum collected from Guizhou Province in China. A total of 22 endophytic Colletotrichum strains were isolated and identified based on both mor- 
phological and molecular characteristics. Five Colletotrichum strains, C. cariniferi, C. chiangraiense, $C$. doitungense, $C$. parallelophorum and $C$. watphraense are introduced as new species. The results of this study will contribute to the knowledge on diversity and phylogeny of Colletotrichum.

\section{Material and methods}

\section{Sample collection}

Healthy roots, stems and leaves of $D$. cariniferum, $D$. harveyanum and three unidentified Dendrobium taxa (referred to as Dendrobium sp. 1, 2 and 3) were collected from Wat Phra That Doi Tung (Temple of Doi Tung Pagoda), Mae Fah Luang District, Chiang Rai, Thailand. Healthy roots, stems and leaves of D. catenatum were collected from Guizhou Province in China. Materials were packed in zip-lock bags or tubes containing silica gel on ice. Fungal isolation was carried out within 48 hours following collection.

\section{Fungal isolation and cultivation}

Surface sterilization and endophyte isolation were carried out as described by Nontachaiyapoom et al. (2010) with some modifications. First, materials were washed with running water. Roots, stems and leaves were immersed in a solution containing 3\%(v/v) $\mathrm{H}_{2} \mathrm{O}_{2}$ and $70 \%(\mathrm{v} / \mathrm{v})$ ethanol for 5 minutes, and then rinsed with sterile distilled water for three times. Sterilized materials were cut into $2 \mathrm{~mm}^{2}$ and placed on potato dextrose agar (PDA) containing $50 \mu \mathrm{g} / \mathrm{ml}$ oxytetracycline, $50 \mu \mathrm{g} /$ $\mathrm{ml}$ penicillin and $50 \mu \mathrm{g} / \mathrm{ml}$ streptomycin (Otero et al. 2002). Samples were incubated at $28{ }^{\circ} \mathrm{C}$ under natural light. Single spores were transferred to fresh PDA to obtain pure cultures. The pure cultures were deposited at China General Microbiological Culture Collection Center (CGMCC), International Collection of Microorganisms from Plants (ICMP) and Mae Fah Luang University Culture Collection (MFLUCC). The dry cultures of new species were deposited in Mae Fah Luang University herbarium (MFLC).

\section{DNA extraction and amplification}

DNA samples were prepared from mycelium of pure fungal culture using EZgene Fungal gDNA Kit (GD2416, Biomiga, USA) as described by the manufacturer. Amplification reactions were performed using reagents purchased from BIOMIGA (San Diego, USA). Each $20-\mu l$ amplification reaction contained $10 \mu \mathrm{l}$ of $2^{*}$ Bench Top Taq Master Mix (0.05 units/ $\mu \mathrm{l}$ Taq DNA polymerase, $0.4 \mathrm{mM}$ dNTPs and $4 \mathrm{mM} \mathrm{MgCl}_{2}$ ); $2 \mu \mathrm{l}$ forward and reverse primers; $1 \mu \mathrm{l}$ of DNA template and $7 \mu \mathrm{l}$ of water. The primers 
Table I. PCR thermal cycling process.

\begin{tabular}{|c|c|c|c|c|c|c|}
\hline \multirow[b]{2}{*}{ Region/gene } & \multicolumn{6}{|c|}{ PCR amplification } \\
\hline & $\begin{array}{c}\text { Initial } \\
\text { denaturation }\end{array}$ & $\begin{array}{c}\text { Cycle } \\
\text { number }\end{array}$ & Denaturation & Annealing & Elongation & Final elongation \\
\hline ITS & $95^{\circ} \mathrm{C} 3 \mathrm{~min}$ & 30 & $95^{\circ} \mathrm{C} 1 \mathrm{~min}$ & $53^{\circ} \mathrm{C} 1 \mathrm{~min}$ & $72{ }^{\circ} \mathrm{C} 1 \mathrm{~min}$ & \\
\hline GAPDH & $95^{\circ} \mathrm{C} 3 \mathrm{~min}$ & 35 & $95^{\circ} \mathrm{C} 1 \mathrm{~min}$ & $60{ }^{\circ} \mathrm{C} 30 \mathrm{~s}$ & $72{ }^{\circ} \mathrm{C} 45 \mathrm{~s}$ & $72^{\circ} \mathrm{C} 10 \mathrm{~min}$ \\
\hline ACT & $95^{\circ} \mathrm{C} 3 \mathrm{~min}$ & 40 & $94^{\circ} \mathrm{C} 45 \mathrm{~s}$ & $52{ }^{\circ} \mathrm{C} 30 \mathrm{~s}$ & $72{ }^{\circ} \mathrm{C} 90 \mathrm{~s}$ & \\
\hline ß-tubulin & $95^{\circ} \mathrm{C} 3$ min & 35 & $94^{\circ} \mathrm{C} 1 \mathrm{~min}$ & $55^{\circ} \mathrm{C} 55 \mathrm{~s}$ & $72^{\circ} \mathrm{C} 1 \mathrm{~min}$ & \\
\hline
\end{tabular}

used in this study were ITS1/ITS4 (White et al. 1990), GDF/GDR (Templeton et al. 1992), 512F/783R (Carbone and Kohn 1999) and BT2A/BT2B (Glass and Donaldson 1995; Maharachchikumbura et al. 2012). The thermal cycling programs are presented in Table 1. PCR products were sent to Invitrogen (USA), Sangon Biotech and Sino GenoMax (China) for purification and sequencing.

\section{Sequence analysis}

Either single-directional sequencing results (for ITS and GAPDH) or bi -directional sequencing results (for ACT and TUB2) were manually trimmed and/or assembled into contigs using CodonCode aligner software (CodonCode Corporation, Dedham, Massachusetts). Through the latest publications and the observation for ML tree topology, a selected set of ITS, GAPDH, ACT and TUB2 sequences especially those of ex-type/ ex-epitype materials used in the phylogenetic analysis were downloaded from GenBank (Table 2). Five datasets of Colletotrichum spp. ITS (134nt), GAPDH (113nt), ACT (119nt), ß-tubulin (125nt) and a concatenated dataset were constructed. Sequences were aligned using MAFFT version 6 (Katoh and Toh 2008; mafft. cbrc. jp/ alignment/ server/). Aligned datasets were visually inspected and misaligned regions were manually edited where necessary using Bio-Edit version 7.2.5 (Hall 1999). Ambiguous regions were trimmed using trimAL version 1.3 (Capella-Gutierrez, Silla-Martinez and Gabaldon 2009) available online through Phylemon 2.0 (http://phylemon.bioinfo.cipf. es/). After trimming, the final alignments contained 578 sites for ITS, 298 sites for GAPDH, 290 sites for ACT and 480 sites for $ß$-tubulin. The concatenated dataset contained a total of 134 taxa and 1646 sites that were used for all subsequent analyses and submitted to TreeBase (http://purl.org/phylo/treebase/phylows/study/TB2:S22431). Gaps were treated as missing data in maximum likelihood (ML), Bayesian inference (BI) and parsimony trees. Parsimony trees were constructed with PAUP (Phylogenetic Analysis Using Parsimony) version 4.0 beta 10 (Swofford 2002). Heuristic searches were conducted as follows: 1000 starting trees were generated using stepwise addition and random addition sequence replicates, followed by branch swapping using the tree-bisection-reconnection (TBR) algorithm. The inferences for MP tree were length $=6732$ steps, $\mathrm{CI}=0.294, \mathrm{RI}=0.760, \mathrm{RC}=0.223, \mathrm{HI}=0.706$. Maximum likelihood analyse 
Table 2. Colletotrichum strains and species isolated from Dendrobium orchids.

\begin{tabular}{|c|c|c|c|c|c|}
\hline Orchid sample & Sample site & Tissue & $\begin{array}{c}\text { Number of } \\
\text { fungal strains }\end{array}$ & Colletotrichum species & Code \\
\hline \multirow{3}{*}{ D. cariniferum } & \multirow{3}{*}{$\begin{array}{l}\text { Chiang Rai, } \\
\text { Thailand }\end{array}$} & Root & 0 & 0 & - \\
\hline & & Stem & 1 & C. cariniferi & MFLUCC 14-0100 \\
\hline & & Leaf & 0 & 0 & - \\
\hline \multirow{3}{*}{ D. harveyanum } & \multirow{3}{*}{$\begin{array}{l}\text { Chiang Rai, } \\
\text { Thailand }\end{array}$} & Root & 0 & 0 & - \\
\hline & & Stem & 0 & 0 & - \\
\hline & & Leaf & 2 & C. orchidophilum & $\begin{array}{l}\text { MFLUCC 14-0161 } \\
\text { MFLUCC 14-0162 }\end{array}$ \\
\hline \multirow{3}{*}{$\begin{array}{l}\text { Dendrobium } \\
\text { sp. } 1\end{array}$} & \multirow{3}{*}{$\begin{array}{l}\text { Chiang Rai, } \\
\text { Thailand }\end{array}$} & Root & 2 & C. parallelophorum & $\begin{array}{l}\text { MFLUCC 14-0077 } \\
\text { MFLUCC 14-0079 }\end{array}$ \\
\hline & & Stem & 3 & C.parallelophorum & $\begin{array}{l}\text { MFLUCC 14-0082 } \\
\text { MFLUCC 14-0083 } \\
\text { MFLUCC 14-0085 } \\
\text { MFLUCC } 14-0086\end{array}$ \\
\hline & & Leaf & 4 & $\begin{array}{l}\text { C. boninense, C. jiangxiense, } \\
\text { C. fructicola }\end{array}$ & $\begin{array}{l}\text { MFLUCC 14-0087 } \\
\text { MFLUCC 14-0091 } \\
\text { MFLUCC 14-0092 }\end{array}$ \\
\hline \multirow{3}{*}{$\begin{array}{l}\text { Dendrobium } \\
\text { sp. } 2\end{array}$} & \multirow{3}{*}{$\begin{array}{l}\text { Chiang Rai, } \\
\text { Thailand }\end{array}$} & Root & 2 & $\begin{array}{l}\text { C. chiangraiense; } C \text {. } \\
\text { fructicola }\end{array}$ & $\begin{array}{l}\text { MFLUCC 14-0119 } \\
\text { MFLUCC 15-0262 }\end{array}$ \\
\hline & & Stem & 3 & $\begin{array}{c}\text { C. boninense, } \\
\text { C. watphraense, C. sp.indet. }\end{array}$ & $\begin{array}{l}\text { MFLUCC 15-0120 } \\
\text { MFLUCC 15-0123 } \\
\text { MFLUCC 15-0124 }\end{array}$ \\
\hline & & Leaf & 3 & C. citricola, C. doitungense & $\begin{array}{l}\text { MFLUCC 15-0128 } \\
\text { MFLUCC 15-0129 } \\
\text { MFLUCC 15-0131 }\end{array}$ \\
\hline \multirow{3}{*}{$\begin{array}{l}\text { Dendrobium } \\
\text { sp. } 3\end{array}$} & \multirow{3}{*}{$\begin{array}{l}\text { Chiang Rai, } \\
\text { Thailand }\end{array}$} & Root & 0 & 0 & - \\
\hline & & Stem & 0 & 0 & - \\
\hline & & Leaf & 1 & C. boninense & MFLUCC 15-0148 \\
\hline \multirow{3}{*}{ D. catenatum } & \multirow{3}{*}{$\begin{array}{l}\text { Xing Yi, } \\
\text { China }\end{array}$} & Root & 0 & 0 & - \\
\hline & & Stem & 0 & 0 & - \\
\hline & & Leaf & 1 & C. boninense & MFLUCC 15-0261 \\
\hline
\end{tabular}

“_” means that no strain was isolated. The strains of new species are in bold font.

was conducted with RAxMLGui 1.31 (Silvestro and Michalak 2012). The general time reversible (GTR) model of nucleotide substitution was used and the inverse gamma distribution option was implemented. The topology of the resulting tree was similar to that of the maximum parsimony tree. Bootstrap support was calculated from 1000 replicates, which were subsequently mapped onto the best-scoring ML tree. Bayesian inference trees were computed using MrBayes version 3.1.2 (Ronquist and Huelsenbeck 2003). The concatenated dataset was partitioned and the ultrafast bootstrap (Minh et al. 2013) implemented in the IQ-TREE software (Nguyen et al. 2015) as well as Mrmodeltest 2.3 (Nylander 2004) were used to estimate the best fitting models according to the Bayesian information criterion (BIC). The GTR model with inverse gamma dis- 
tribution and HKY model with gamma distribution were used as the most appropriate for the ITS and GAPDH respectively. The Hasegawa, Kishino \& Yano (HKY) model with inverse gamma distribution and GTR model with gamma distribution were selected for the ACT and $\beta$-tubulin datasets. Two sets of four simultaneous independent chains of Markov chains Monte Carlo (MCMC) simulations were run for 6,000,000 generations, $25 \%$ of trees were discarded as burn-in and the remaining trees were used to calculate the posterior probabilities. Convergence was assumed when the standard deviation of split sequences was less than 0.01 . The fungal isolates and sequences of region/genes used in Colletotrichum phylogenetic analysis are listed in Appendix A.

\section{Morphological analysis}

Sporulation of studied fungi was induced on thin pieces of Corn malt agar medium (CMA). The strains that did not sporulate on CMA were cultured on PDA or Sabouraud dextrose agar (SDA) with sterilized orchid tissues in order to induce sporulation. An autoclaved toothpick was placed on CMA for one strain C. cariniferi to induce sporulation. Cultures were grown in a dark cabinet at room temperature $\left(28^{\circ} \mathrm{C}\right)$ and observed for every seven days or less. The growth rate was evaluated when mycelia nearly covered the whole medium surface. Once an acervuli or ascomata were observed, photos were taken with a stereomicroscope (SteREO Discovery. V8, Carl Zeiss Microscopy GmBH, Germany). Cross-sections and conidiomata crushed in water were observed under a compound microscope (EOS 600D, Nikon, Japan). Ascomata and conidiomata were observed under a Motic SMZ-140 microscope (China). Conidiophore, conidia, appressoria, ascomata, asci, ascospores and other visible structures such as chlamydospore were used for evaluating morphological characteristics in this study (Damm et al. 2014). The recommendations of Jeewon and Hyde (2016) were followed in establishing new species.

\section{Results}

\section{Fungal isolation and Identification}

Twenty-two endophytic Colletotrichum strains were isolated from six Dendrobium species (Table 2). The highest number of Colletotrichum strains and species were isolated from Dendrobium sp. 1 followed by Dendrobium sp.2. All three tissue types of the two orchids hosted at least one strains of Colletotrichum. Among the three tissue types, the highest number of Colletotrichum strains and species were isolated from leaves. Colletotrichum boninense and C. fructicola were respectively the most frequently isolated Colletotrichum species. Interestingly, C. boninense was isolated from Dendrobium species collected from both geographical areas studied (i.e., Chiang Rai, Thailand and Guizhou, China). 


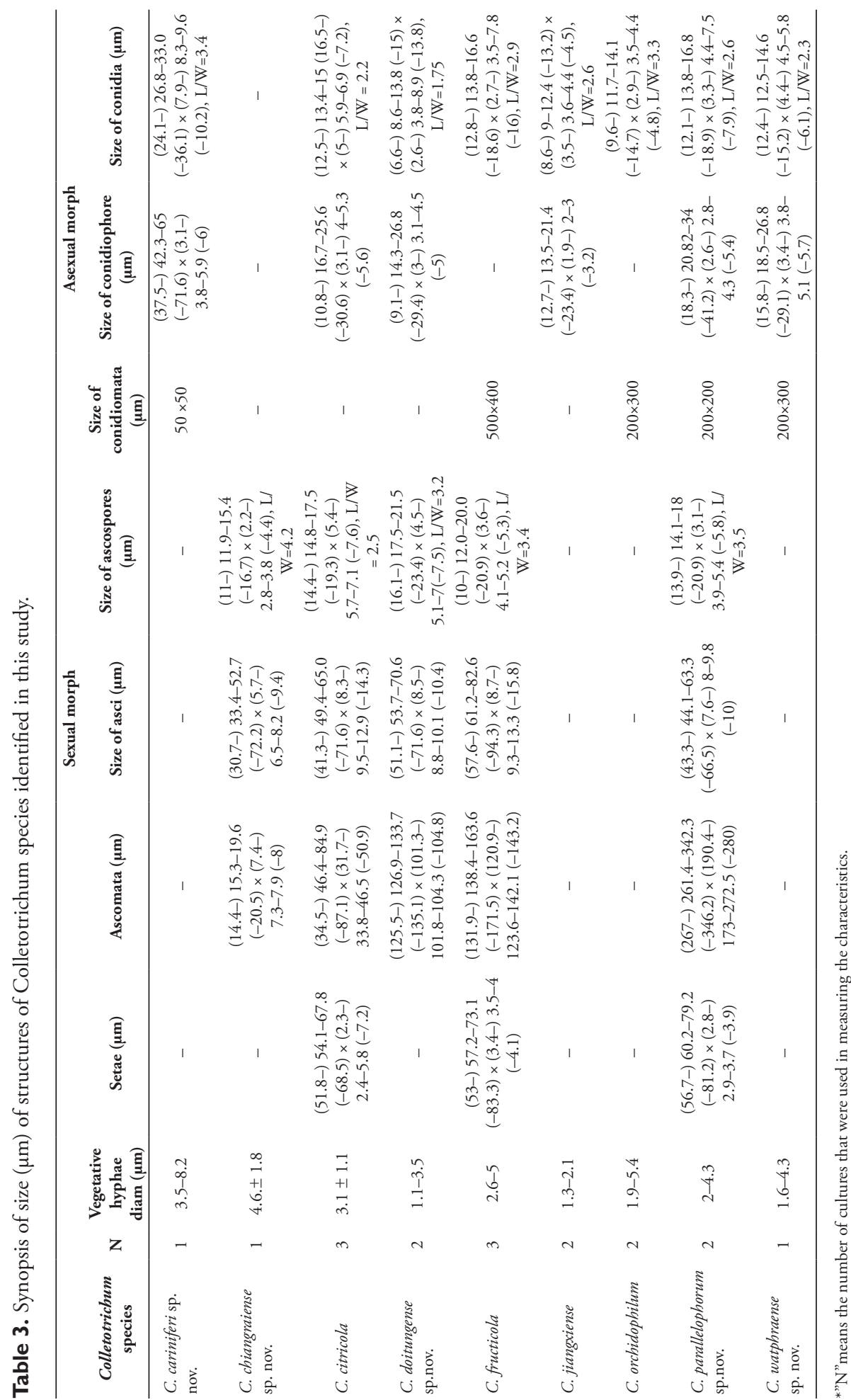




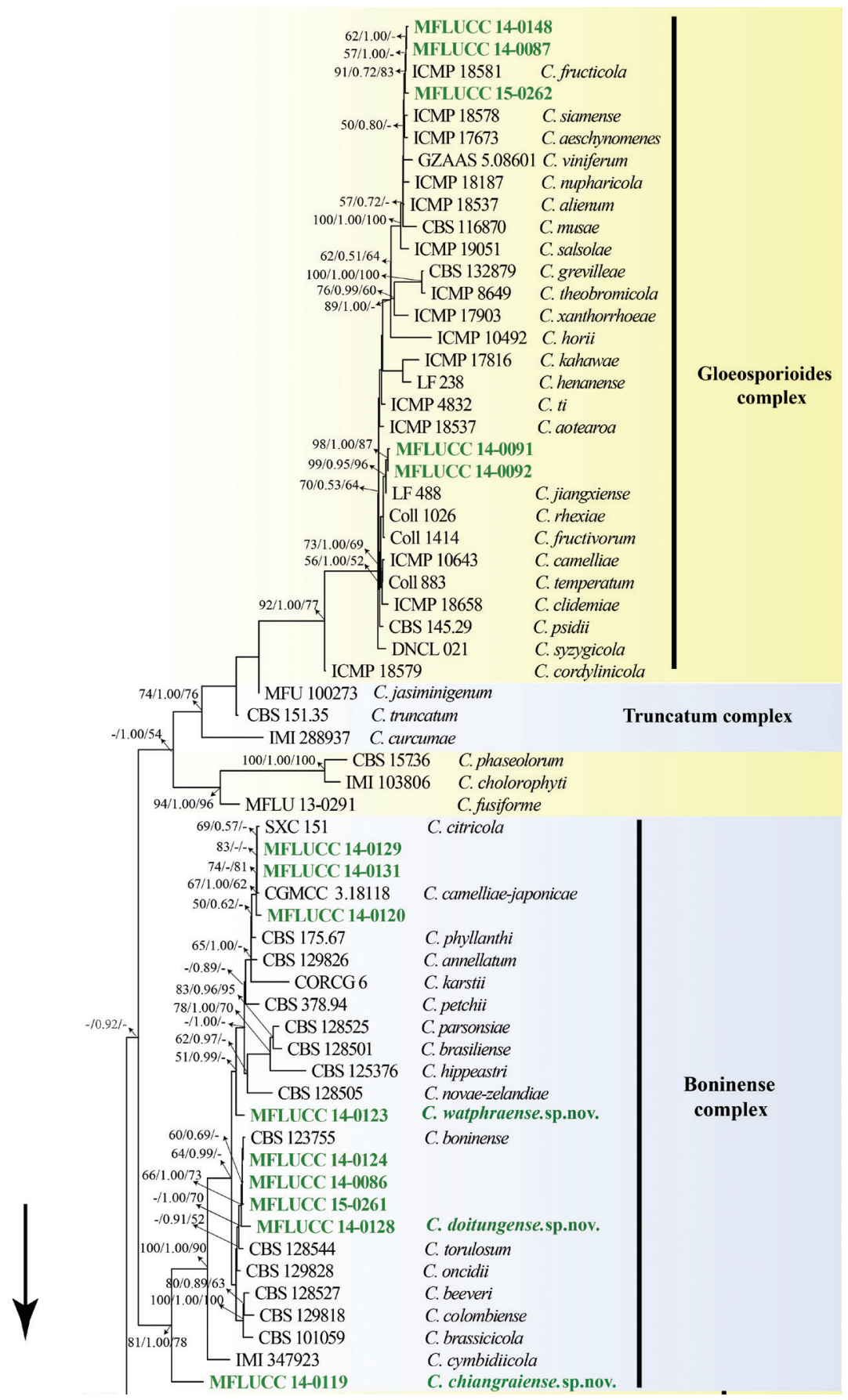

Figure I. Maximum likelihood (ML) tree of Colletotrichum inferred from 134 taxa and 1646 sites from a concatenated dataset containing ITS, GAPDH, ACT and B-tubulin sequence data. Values at nodes indicate bootstrap percentages (BP) for ML, Bayesian posterior probabilities (PP) and $\mathrm{BP}$ for maximum parsimony (MP) in this order. Only BP over $50 \%$, PP over 0.50 and MP over 50 are shown. Dashes correspond to lower than the above-mentioned values. The isolated fungal endophytes in this study are shown in green bold text. Scale bar corresponds to 0.08 substitutions per site. “*” indicates the new species. 


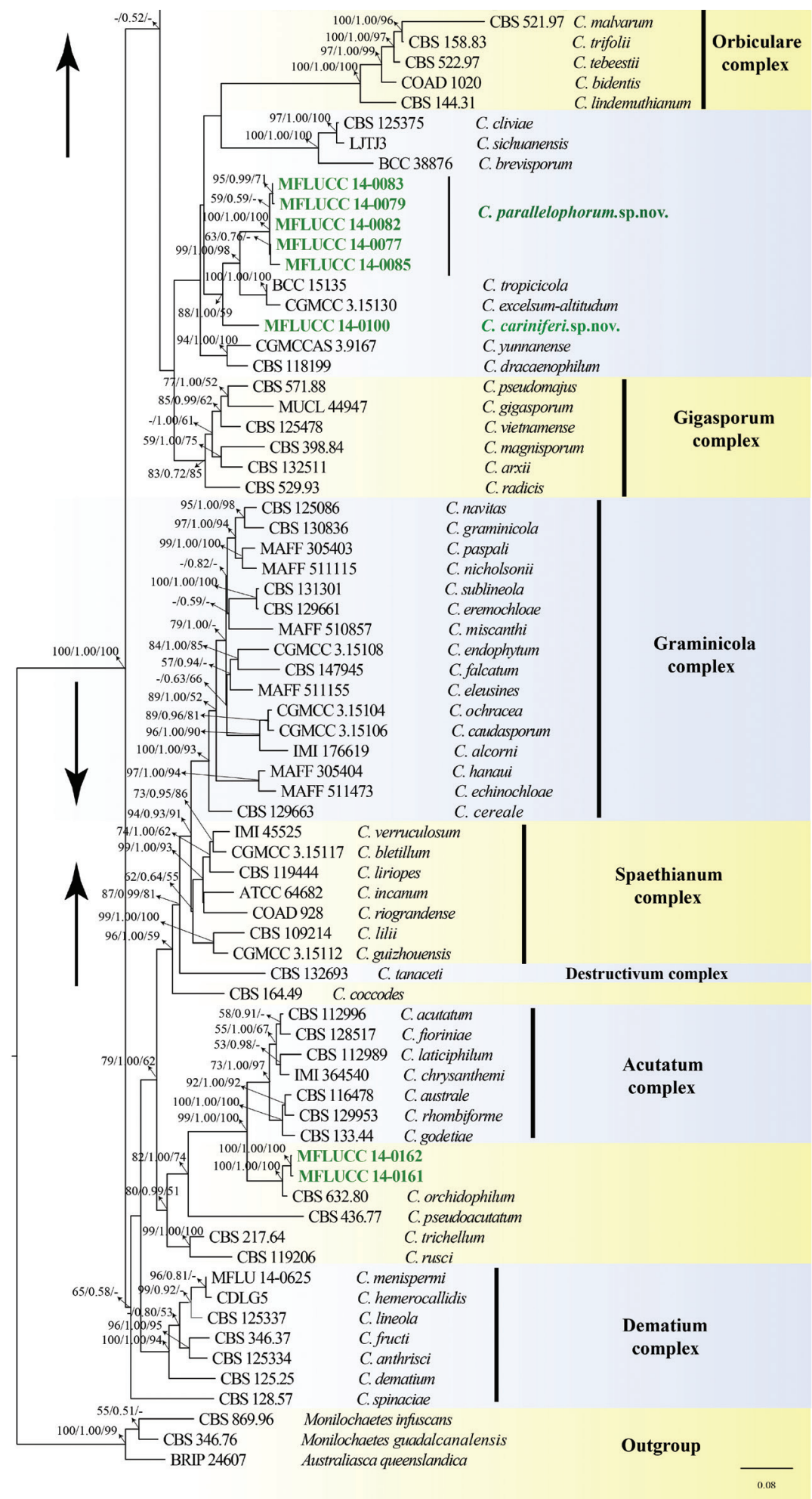

Figure I. Continued. 


\section{Sporulation results}

All Colletotrichum strains could grow on three kinds of media. Colletotrichum citricola, C. doitungense, C. fructicola and C. parallelophorum produced both sexual and asexual morphs in culture. Colletotrichum boninense, C. cariniferi, C. orchidophilum and $C$. watphraense produced only the asexual morph and $C$. chiangraiense produced only sexual morph in culture. Measurements of important vegetative and reproductive characteristics of isolated strains are given in Table 3.

\section{Phylogenetic results}

\section{Phylogenetic analyses}

All the sequences of ITS, GAPDH, ACT and $\beta$-tubulin of 22 strains of Colletotrichum obtained in this study were deposited in GenBank (List in Appendix B). The three selected outgroup species (i.e. Australiasca queenslandica BRIP 24607; Monilochaetes infuscans CBS 869.96 and Monilochaetes guadalcanalensis CBS 346.76) formed a strongly supported cluster (100ML/1.00BI/99MP). The ingroup consisted of all Colletotrichum sequences and was fully supported by all three methods of analysis (100ML/1.00BI/100MP). Five strains grouped within the gloeosporioides complex: MFLUCC 14-0087, MFLCCC 14-0091, MFLUCC 14-0092,

MFLUCC 14-0148 and MFLUCC 14-0262. The sequences of MFLCCC 14-0091 and MFLUCC 14-0092 were nearly identical and close to $C$. jiangxiense with strong support (99ML/0.95BI/96MP). MFLUCC 14-0087, MFLUCC 14-0148 and MFLUCC 15-0262 clustered with $C$. fructicola (ICMP 181873) (91ML/0.72BI/83MP).

Nine of the newly sequenced strains clustered within the boninense species complex: MFLUC 14-0086, MFLUCC 14-0119, MFLUCC 14-0120, MFLUCC 14-0123, MFLUCC 14-0124, MFLUCC 14-0128, MFLUCC 14-0129, MFLUCC 14-0131, MFLUCC 15-0261. MFLUCC 14-0086, MFLUCC 14-0124 and MFLUCC 14-0261 shared very similar sequences. MFLUCC 14-0128 grouped as sister to the three abovementioned strains (66ML/1.00BI/73MP). MFLUCC 14-0123 formed a separated clade from other species by only Bayesian analysis (1.00BI). MFLUCC 14-0120, MFLUCC 14-0129 and MFLUCC 14-0131 formed a cluster with C. camelliae-japonicae and C. fructicola (76ML/1.00BI/62MP). MFLUCC 14-0120 and MFLUCC 14-0129 differed by only three base pairs in trimmed concatenated alignment. MFULCC 14-0119 was placed basally to the boninense species complex with strong support (100ML/0.96BI/90MP).

MFLUCC 14-0161 and MFLUCC 14-0162 grouped outside the currently accepted species complexes. The two had a close relationship and formed a clade with $C$. orchidophilum, which is a singleton and a sister taxon to the acutatum species complex. They hold the maximum support with all three methods of analysis. Colletotrichum orchidophilum differed $1.5 \%$ and $1.3 \%$ with MFLUCC 14-0161 and MFLUCC 14-0162 respectively. MFLUCC 14-0077, MFLUCC 14-0079, MFLUCC 14-0082, MFLUCC 
14-0083 and MFLUCC 14-0085 formed a novel clade (100ML/1.00BI/100MP), which grouped as sister clade to the $C$. excelsum-altitudum/C. tropicicola clade and MFLUCC 14-0100 (88ML/1.00BI/59MP). MFLUCC 14-0100 took a solo branch in the basal position among them (99ML/1.0BI/98MP).

\section{Taxonomy}

The 22 strains isolated as endophytes were assigned to eleven species, five known species, five new species and one undetermined species. We obtained the sexual and asexual morphs for four strains. The sexual morph only was obtained in the case of $C$. chiangraiense. The descriptions of the fungal endophytes identified in this study are as follows.

\section{Colletotrichum cariniferi X.Y. Ma, K.D. Hyde \& Jayawardena, sp.nov.} Fungal Name Number: FN570511

Etymology. In reference to the host epithet cariniferum.

Holotype. MFLC 17-1199 (ex-holotype culture: MFLUCC 14-0100).

Description. Sexual morph not observed.

Asexual morph on CMA. Vegetative hyphae 3.5-8.2 $\mu \mathrm{m}$ diam $(\mathrm{N}=20)$, hyaline to brown, smooth-walled, septate, branched. Appressoria (9.7-) 10.4-17 (-20.5) × (6.5-) 7.1-11.3 (-13.6) $\mu \mathrm{m}(\mathrm{N}=6)$, globose to sub-globose, light brown. Conidiomata $50 \times$ $50 \mu \mathrm{m}(\mathrm{N}=10)$, developing with mycelia, globose to irregular, milk orange to orange, in mass brown. Conidiophores (37.5-) 42.3-65 (-71.6) × (3.1-) 3.8-5.9 (-6) $\mu \mathrm{m}(\mathrm{N}=6)$, smooth-walled, unbranched, hyaline. The part connected with conidia of conidiogenous cell inflated and some with large guttules. Conidia (24.1-) 26.8-33.0 (-36.1) $\times(7.9-)$ 8.3-9.6 (-10.2) $\mu \mathrm{m}(\mathrm{N}=30), \mathrm{L} / \mathrm{W}=3.4$, ellipsoidal to cylindrical, with one end inflated when immature state, both ends rounded when mature, with 2 to 3 guttules, hyaline.

Cultures on CMA flat with entire margin. Growth rate: $0.23 \mathrm{~cm} /$ day, with 50 -days for sporulation. Cottony, pale cinnamon to light brown, scattered pale mycelia in spots around the middle inoculum clump, sometimes covered short, floccose-felty, white, aerial mycelium, reverse buff brown.

Material examined. Thailand, Chiang Rai, Wat Phra That Doi Tung (Temple of Doi Tung Pagodas), the host Dendrobium cariniferum was sampled on 19 December 2013, Collector: Sureeporn Nontachaiyapoom, Natdanai Aewsakul, Xiaoya Ma.

Notes. Colletotrichum cariniferi (MFLUCC 14-0100) clusters in a separate branch with a good support (88ML/1.00BI/59MP). The species is most phylogenetically close to Colletotrichum excelsum-altitudum and C. tropicicola, but they are morphologically different. C. cariniferi holds 77 and 91 different base pairs compared with C. tropicicola and C. excelsum-altitudum respectively. Colletotrichum cariniferi has much larger conidia than that of closely related strains in the tree (conidia (24.1-) 26.8-33 (-36.1) $\times(7.9-)$ 8.3$9.6(-10.2) \mu \mathrm{m}(\mathrm{N}=30), \mathrm{L} / \mathrm{W}=3.4$ vs. conidia of $C$. tropicicola $13-16.5 \times 5-7 \mu \mathrm{m}$ and $C$. 

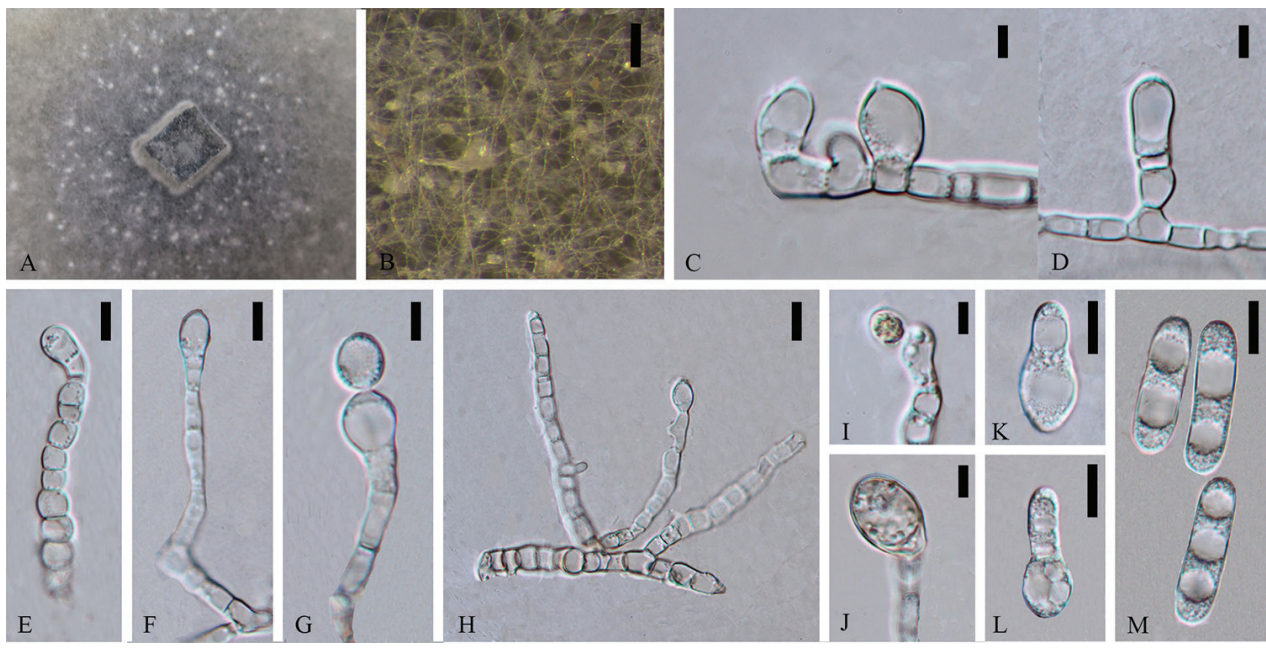

Figure 2. Colletotrichum cariniferi (holotype). A Colony B Conidiomata C, I-J Appressoria D-H Conidiophores K-M Conidia. Scale bars: $100 \mu \mathrm{m}$ (B), $5 \mu \mathrm{m}$ (C-D), $10 \mu \mathrm{m}(\mathbf{E}-\mathbf{H}), 5 \mu \mathrm{m}(\mathbf{I}-\mathbf{M})$.

excelsum-altitudum $14.8 \pm 0.8 \times 5.8 \pm 0.4 \mu \mathrm{m}$ ) (Noireung 2012; Tao et al. 2013). Blastn searches with sequence of MFLUCC 14-0100 resulted in 100\% matches with ITS sequence of endophytic Colletotrichum sp. strain S4 isolated from Dendrobuim nobile in China (GenBank FJ042517, Yuan et al. 2009) and 96\% identity with TUB2 sequences of C. arxii strain CBS 169.59 isolated from Oncidium excavatum (GenBank KF687868, Liu et al. 2014) in Netherlands and another C. arxii strain CBS 132511 isolated from Paphlopedilum sp. in Germany (GenBank KF687881, Liu et al. 2014) respectively. Colletotrichum cariniferi from stems of $D$. cariniferum is introduced as a new species.

\section{Colletotrichum chiangraiense X.Y. Ma, K.D. Hyde \& Jayawardena, sp.nov.} Fungal Name Number: FN570512

Figure 3

Etymology. In reference to the host sample site Chiang Rai, Thailand.

Holotype. MFLU 17-1201 (ex-holotype culture: MFLUCC 14-0119).

Description. Asexual morph not observed.

Sexual morph on CMA. Vegetative hyphae 4.6. $1.8 \mu \mathrm{m}$ diam $(\mathrm{N}=20)$, hyaline to pale brown, smooth-walled, septate, branched. Chlamydospore globose, brown. Hyphae fusion and crozier observed. Ascomata rare, covered by mycelia, black. Appressoria (14.4-) 15.3-19.6 (-20.5) $\times(7.4-)$ 7.3-7.9 (-8) $\mu \mathrm{m}(\mathrm{N}=2)$, single, outline ampulliform or ovate, pale brown. Asci (30.7-) 33.4-52.7 (-72.18) × (5.7-) 6.5-8.2 $(-9.4) \mu \mathrm{m}(\mathrm{N}=15)$, cylindrical, straight to curved, unitunicate, 8 -spored. Ascospores (11-) 11.9-15.4 (-16.7) × (2.2-) 2.8-3.8 (-4.4) $\mu \mathrm{m}(\mathrm{N}=20), \mathrm{L} / \mathrm{W}=4.2$, bi-seriately, smooth-walled, cylindrical or fusiform, one guttule in the middle, hyaline.

Cultures on CMA flat with entire margin. Growth rate: $0.6 \mathrm{~cm} /$ day, with 20 -days for sporulation. Fluffy, dark green in the middle and white margin, reverse black in the middle. 

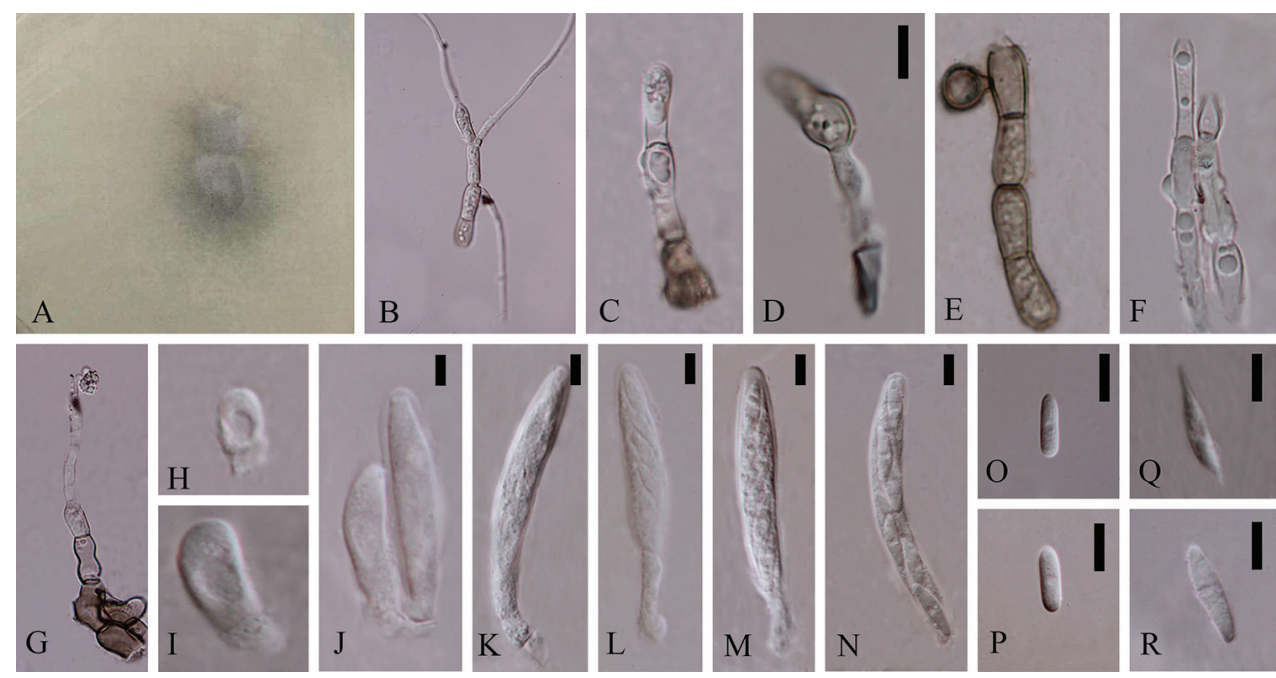

Figure 3. Colletotrichum chiangraiense (holotype). A Colony B Spore germination C Conidiophore D Appressoria E Chlamydospore $\mathbf{F}$ Mycelia fusion $\mathbf{G}$ Crozier $\mathbf{H}-\mathbf{N}$ Asci O-R Ascospores. Scale bars: $20 \mu \mathrm{m}(\mathbf{D}), 20 \mu \mathrm{m}(\mathbf{G}), 5 \mu \mathrm{m}(\mathbf{J}-\mathbf{N}), 10 \mu \mathrm{m}(\mathbf{O}-\mathbf{R})$.

Material examined. Thailand, Chiang Rai, Wat Phra That Doi Tung (Temple of Doi Tung Pagodas), the host Dendrobium sp.2 was collected on 19 December 2013, Collector: Sureeporn Nontachaiyapoom, Natdanai Aewsakul, Xiaoya Ma.

Notes. Colletotrichum chiangraiense (MFLUCC 14-0119) formed a single branch with the support of $81 \mathrm{ML} / 1.00 \mathrm{BI} / 78 \mathrm{MP}$ in boninense species complex. It has 125 different base pairs (mainly in ITS and ACT) from the closest strain C. cymbidiicola. Blastn searches with sequences of MFLUCC 14-0119 resulted in 99\% identity with ITS of the endophytic C. crassipes strain DO93 (GenBank KP050648) isolated from Dendrobium officinale in China (Unpublished), $99 \%$ identity with ACT of the endophytic Colletotrichum sp. strain COAD 2105 (GenBank KY407893) isolated from Cattleya jongheana in Brazil (Unpublished), 98\% identity with TUB2 of the endophytic C. boninense strain CBS 125502 (GenBank KJ955336) isolated from Camellia sinensis in China (Liu et al. 2015) and 98\% identity with TUB2 of the endophytic $C$. boninense strain CGMCC 3.15165 (GenBank KC244156) isolated from Bletilla ochracea in China (Tao et al. 2013). This species was observed antheridium, mycelia fusion and crozier, which indicates that this species may be homothallic. Here we introduce the strain isolated from root of Dendrobium sp.2 as a new species.

\section{Colletotrichum watphraense X.Y. Ma, K.D. Hyde \& Jayawardena, sp. nov.}

Fungal Name Number: FN570513

Figure 4

Etymology. In reference to the host sample site - Wat Phra temple in Chiang Rai, Thailand. 

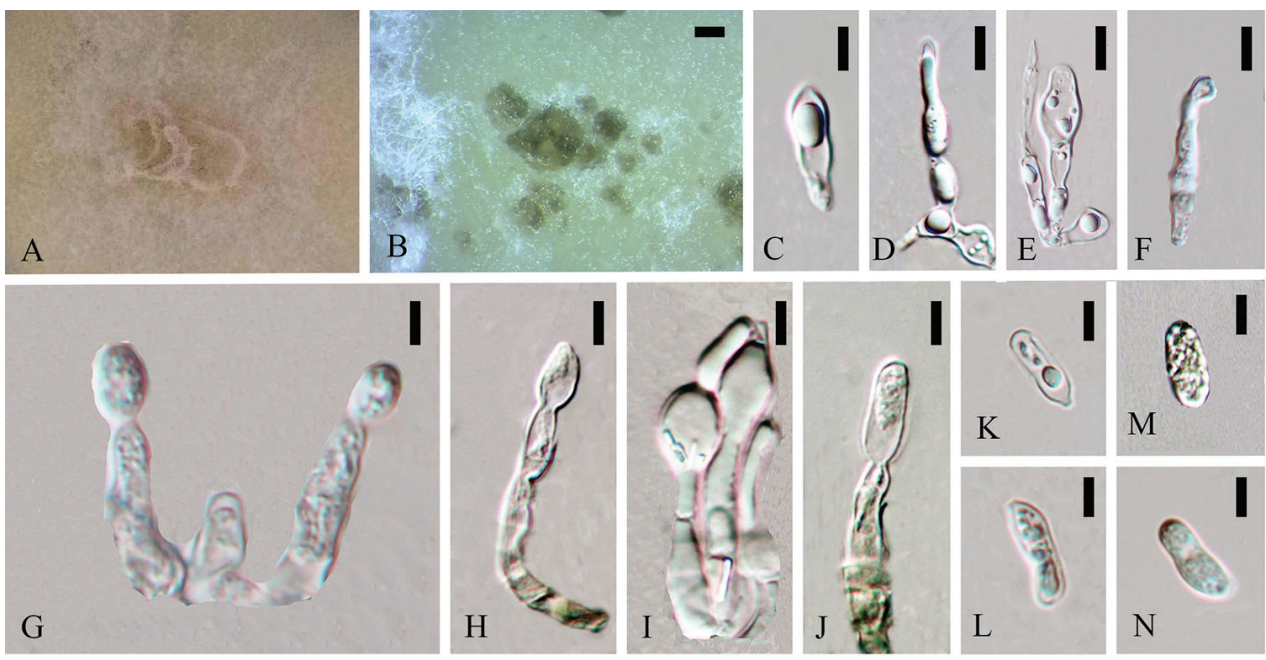

Figure 4. Colletotrichum watphraense (holotype). A Colony B Fruiting body C-J Conidiophores K-N Conidia. Scale bars: $200 \mu \mathrm{m}(\mathbf{B}), 5 \mu \mathrm{m}(\mathbf{C}-\mathbf{N})$.

Holotype. MFLU 17-1202 (ex-holotype culture: MFLUCC 14-0123).

Description. Sexual morph not observed.

Asexual morph on CMA. Vegetative hyphae 1.6-4.3 $\mu \mathrm{m}$ diam ( $=20)$, smoothwalled, septate, branched, hyaline. Chlamydospores and appressoria not observed. Conidiomata $200 \times 300 \mu \mathrm{m}$, brown, Conidiophores (15.8-) 18.5-26.8 (-29.1) × (3.4-) 3.8$5.1(-5.7) \mu \mathrm{m}(\mathrm{N}=16)$, smooth-walled, septate, branched or single, periclinal thickening, hyaline. Conidia (12.4-) 12.5-14.6 (-15.2) × (4.4-) 4.5-5.8 (-6.1) $\mu \mathrm{m}(\mathrm{N}=5), \mathrm{L} / \mathrm{W}$ $=2.3$, aseptate, ellipsoidal, single guttules in the middle, the one part inflated, hyaline.

Cultures on CMA flat with entire margin. Growth rate: $0.45 \mathrm{~cm} /$ day, with 30 -days for sporulation. Fluffy, white to light buff orange. Perithecia isolated. Acervuli under white cotton-like mycelia, irregular, asymmetrical surface, light brown to brown.

Material examined. Thailand, Chiang Rai, Wat Phra That Doi Tung (Temple of Doi Tung Pagodas), the host Dendrobium sp.2 was collected on 19 December 2013, Collector: Sureeporn Nontachaiyapoom, Natdanai Aewsakul, Xiaoya Ma.

Note. MFLUCC 14-0123 formed a singular branch with other species and only supported by $1.00 \mathrm{BI}$ in boninense species complex. There were 42bp $(2.6 \%)$ and 85bp (5.2\%) differences in GAPDH between Colletotrichum watphraense and its close strains Colletotrichum boninense/C. novae-zelandiae respectively. The closest matches in a blastn search with ITS sequences of the strain MFLUCC 14-0123 are C. cymbidiicola strain FS21 (GenBank KP689224) iaolated from a rare medical plant Huperzia serrata with 99\% identity in China (Wang et al. 2016), C. gloeosporioides strain Trtsf02 (GenBank GU479899) isolated from Trillum tschonoskii with 99\% identity in China (Unpublished) and pathogenic C. boninense strain CO5016 (GenBank GU935883) isolated from ginseng with 99\% identity in Korea (Unpublished). GAPDH and ACT sequences blastn results showed its closest matches are pathogenic $C$. citricola strain 
SXC 151 (GenBank KC293736) isolated from Proteaceae with 99\% identity in Netherlands (Liu et al. 2012) and C. boninense strain CBS 125502 (GenBank KJ954462) isolated from Camellia sp. with 99\% identity in unknown locality (Liu et al. 2015). Blastn search with TUB2 sequence results in 99\% identity with two $C$. boninense strains CBS 125502 (GenBank KJ955336) and the strain CGMCC 3.15165 (GenBank KC244156) as mentioned above. The conidiophores were much longer $(40 \mu \mathrm{m}$ long) in C. boninense. Conidia of the strain CBS 123755 have straight, cylindrical to clavate, conidia with a rounded apex; and base with a prominent hilum, sometimes with two large polar guttules, which is different from Colletotrichum watphraense. Here we assigned the strain isolated from stem of Dendrobium sp.2 as a new species.

\section{Colletotrichum doitungense X.Y. Ma, K.D. Hyde \& Jayawardena, sp.nov.} Fungal Name Number: FN570514

Figure 5

Etymology. In reference to the host sample site Doi tung, Chiang Rai, Thailand.

Holotype. MFLU 17-1200 (ex-holotype culture: MFLUCC 14-0128).

Description. Asexual morph on CMA. Vegetative hyphae 1.1-3.5 $\mu \mathrm{m}$ diam, hyaline, smooth-walled, septate, branched. Setae and chlamydospores not observed. Conidiomata and ascomata cluster together. Conidiophores (9.1-) 14.3-26.8 (-29.4) x (3-) 3.1-4.5 (-5) $\mu \mathrm{m}$, smooth-walled, unbranched, septate, constricted septum, hyaline. Conidiogenous cell (3.1-) 3.2-5.8 (-7.5) × (2.6-) 3-4 (-4.5) $\mu \mathrm{m}(\mathrm{N}=14)$, globose to sub-globose, smooth-walled, hyaline. Conidia (6.6-) 8.6-13.8 (-15) $\times(2.6-)$ 3.8-8.9 (-13.8) $\mu \mathrm{m}(\mathrm{N}=22), \mathrm{L} / \mathrm{W}=1.75$, globose to ellipsoidal, both ends rounded, smooth-walled, hyaline.

Sexual morph on CMA. Ascomata (125.5-) 126.9-133.7 (-135.1) × (101.3-) 101.8-104.3 (-104.8) $\mu \mathrm{m}(\mathrm{N}=10)$, sub-globose, closed, pale brown to brown. Peridium 3-11.5 $\mu \mathrm{m}$ thick, Asci (51.1-) 53.7-70.6 (-71.6) × (8.5-) 8.8-10.1 (-10.4) $\mu \mathrm{m}(\mathrm{N}=8)$, cylindrical, slight curved, composed of pale to medium brown flattened angular cells, unitunicate, smooth-walled, 8-spored, hyaline. Ascospores (16.1-) 17.5-21.5 (-23.4) $\times(4.5-)$ 5.1-7.0 (-7.5) $\mu \mathrm{m}(\mathrm{N}=20), \mathrm{L} / \mathrm{W}=3.2$, fusiform, blunt to somewhat acute or acute both ends, single guttule in the middle, septate, bi-seriately, smooth-walled, hyaline.

Cultures on CMA flat with entire margin. Fluffy, white, reverse same. Growth rate: $0.6 \mathrm{~cm} /$ day, with 20-days for sporulation. Brown ring in the middle. Perithecia gregarious. Acervuli and ascomata in mass light brown to brown.

Material examined. Thailand, Chiang Rai, Wat Phra That Doi Tung (Temple of Doi Tung Pagodas), the host Dendrobium sp.2 was collected on 19 December 2013, Collector: Sureeporn Nontachaiyapoom, Natdanai Aewsakul, Xiaoya Ma.

Notes. Colletotrichum doitungense form an independent lineage from other strains with good support (66ML/1.00BI/73MP) in boninense species complex. The ITS sequence of MFLUCC 14-0128 100\% matches with unpublished pathogenic C. cymbidiicola strain OORC18 (GenBank JX902424) isolated from orchid in India and C. karstii 

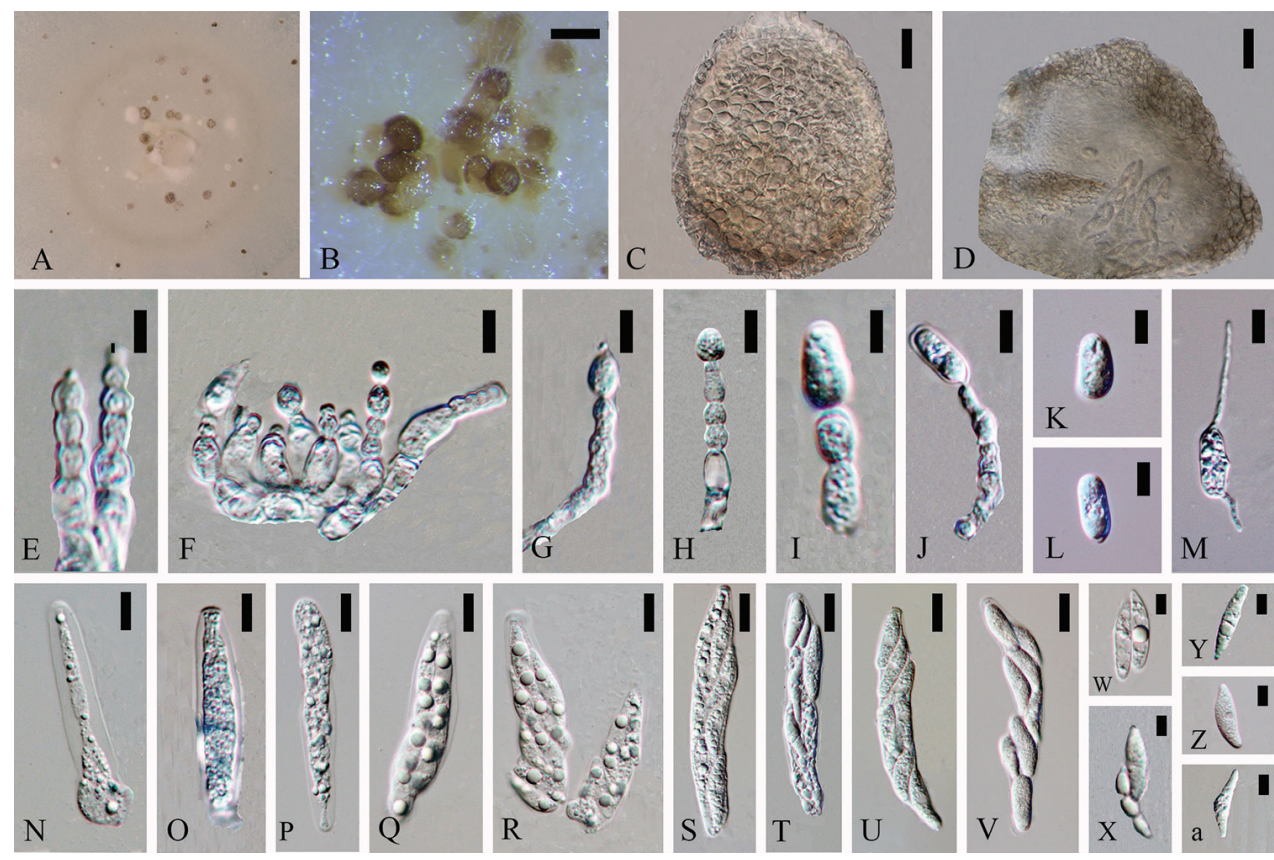

Figure 5. Colletotrichum doitungense (holotype). A Colony B Fruiting body C-D Ascomata E-J Conidiophores K-L Conidia M Spore germination N-V Asci W-a Ascospores. Scale bars: $100 \mu \mathrm{m}$ (B), $20 \mu \mathrm{m}$ (C-D), $5 \mu \mathrm{m}$ (E-M), $10 \mu \mathrm{m}(\mathbf{N}-\mathbf{V}), 5 \mu \mathrm{m}(\mathbf{W}-\mathbf{a})$.

strain R001 (GenBank JN715846) isolated from blackberry in Colombia (Unpublished). Blastn researches with sequences of MFLUCC 14-0128 results in 98\% identity with GAPDH sequence of endophytic C.boninense strain CGMCC 3.15168 (GenBank KC843491) isolated from Bletilla ochracea in China (Tao et al. 2013), 99\% identity with ACT sequence of $C$. boninense strain CBS 125502 (GenBank KJ954462) and 99\% identity with TUB2 sequence of C. citricola strain SXC 151 (GenBank KC293656) as mentioned above. Its conidiogenus cell is globose to sub-globose, which differ from cylindrical to ellipsoidal conidiogenus cell in C. boninense (Damm et al. 2012). This strain has 2 and 0 in ITS, 6 and 1 in GAPDH, 3 and 2 in ACT, 17 and 16 base pair differences from its sister taxon C. torulosum and MFLUCC 14-0261 respectively. Here we introduce Colletotrichum doitungense isolated from root of Dendrobium sp.2 as a new species.

\section{Colletotrichum parallelophorum X.Y. Ma, K.D. Hyde \& Jayawardena, sp. nov.}

Fungal Name Number: FN570515

Figure 6

Etymology. In reference to the parallel conidiophores.

Holotype. MFLU 17-1198 (ex-holotype culture: MFLUCC 14-0083).

Description. Asexual morph on CMA. Vegetative hyphae 2-4.3 $\mu \mathrm{m}$ diam $(\mathrm{N}=30)$, smooth-walled, septate, branched, hyaline to pale brown. Chlamydospores not ob- 

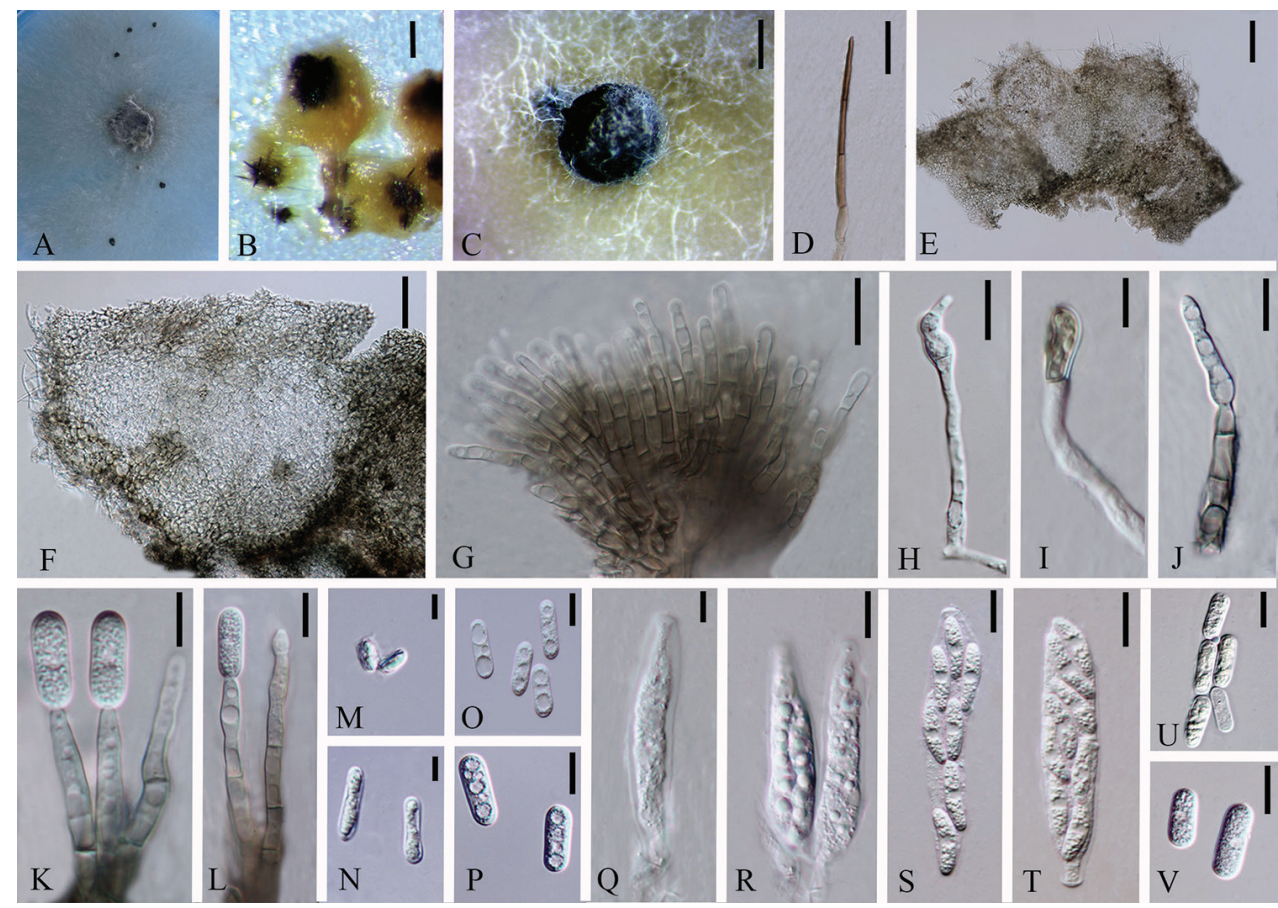

Figure 6. Colletotrichum parallelophorum (holotype). A Colony B, C Fruiting body D Setae E-F Ascomata G, J-L Conidiophores I Appressoria M-P Conidia Q-T Asci U-V Ascospore. Scale bars: $50 \mu \mathrm{m}(\mathbf{B})$, $500 \mu \mathrm{m}(\mathbf{C}), 20 \mu \mathrm{m}(\mathbf{D}), 100 \mu \mathrm{m}(\mathbf{E}), 50 \mu \mathrm{m}(\mathbf{F}), 20 \mu \mathrm{m}(\mathbf{G}), 10 \mu \mathrm{m}(\mathbf{H}-\mathbf{L}), 5 \mu \mathrm{m}(\mathbf{M}, \mathbf{N}), 10 \mu \mathrm{m}(\mathbf{O}-\mathbf{V})$.

served. Conidiomata acervular, orange. Appressoria (56.7-) 60.2-79.2 (-81.2) $\times(2.8-)$ 2.9-3.7 (-3.9) $\mu \mathrm{m}(\mathrm{N}=8)$, single, sub-globose, brown, rare. Conidiophores and setae formed on a cushion of pale brown cells (1.9-) 2.4-4 (-4.6) $\mu \mathrm{m}$ diam. Setae medium brown, smooth-walled, 2 or 3 -septate; base cylindrical, constricted at the base, apex acute. Conidiophores (18.3-) 20.8-34 (-41.2) × (2.6-) 2.8-4.3 (-5.4) $\mu \mathrm{m}(\mathrm{N}=20)$, smooth-walled, 2 to 3 -septate, branched, hyaline to pale brown. Conidiophores and setae formed on a cushion of pale brown prismatic cells, sometimes with guttules. Conidia (12.1-) 13.8-16.8 (-18.9) × (3.3-) 4.4-7.5 (-7.9) $\mu \mathrm{m}(\mathrm{N}=50), \mathrm{L} / \mathrm{W}=2.6$, hyaline, smooth-walled, with 1 to 4 guttules, cylindrical with both ends rounded.

Sexual morph on CMA. Ascomata (267-) 261.4-342.3 (-346.2) × (190.4-) 173.0-272.5 $(-280) \mu \mathrm{m}(\mathrm{N}=3)$, globose, glabrous, Ascomata isolated, scattered, irregular and asymmetrical, black. Peridium 13.6-46.4 $\mu \mathrm{m}$ thick, consist of pale to medium brown flattened angular cells. Ascogenous hyphae hyaline, smooth-walled. Asci (43.3-) 44.1-63.3 (-66.5) × (7.6-) 8.0-9.8 (-10) $\mu \mathrm{m}(\mathrm{N}=7)$, cylindrical, straight, unitunicate, 8-spored. Ascospores (13.9-) 14.1-18 (-20.9) $\times(3.1-)$ 3.9-5.4 (-5.8) $\mu \mathrm{m}(\mathrm{N}=23), \mathrm{L} / \mathrm{W}=3.5$, uni-to bi-seriately, aseptate, smooth-walled, ellipsoidal, single guttules in the middle, both ends rounded, hyaline.

Cultures on CMA flat with entire margin. Growth rate: $0.4 \mathrm{~cm} / \mathrm{d}$, with 20 -days for sporulation. With fluffy, light green and white mycelia. Ascomata sometimes growing together with acervuli. 
Material examined. Thailand, Chiang Rai, Wat Phra That Doi Tung (Temple of Doi Tung Pagodas), the host Dendrobium sp.1 was collected on 19 December 2013, Collector: Sureeporn Nontachaiyapoom, Natdanai Aewsakul, Xiaoya Ma.

Notes. Strains MFLUCC 14-0077, MFLUCC 14-0079 and MFLUCC 140083 had identical sequence data and they formed a single clade with MFLUCC 14-0082 and MFLUCC 14-0085. They are closely related to Colletotrichum excelsum-altitudum and C. tropicicola. MFLUCC 14-0077, MFLUCC 14-0079, MFLUCC 14-0082, MFLUCC 14-0083 and MFLUCC 14-0085 have similar morphological characteristics. Therefore, the five strains are regarded as the same species. There were totally $103 \mathrm{bp}$ and $101 \mathrm{bp}$ differences between MFLUCC 140083 and $C$. excelsum-altitudum/C. tropicicola respectively (mainly in GAPDH). Blastn researches with four-gene sequences of five strains presented $99 \%$ identity with ITS sequence of $C$. cordylinicola strain LC0886, 80\% identity with GAPDH (GenBank JN050229), 90\% identity with ACT (GenBank JN050218) and 93\% identity with TUB2 (GenBank JN050246) sequences of C. tropicola strain LC0598 respectively as mentioned above. Conidia size and shape were very similar among MFLUCC 14-0083, C. excelsum-altitudum and C. tropicicola. Appressoria were rare and in strain MFLUCC-14-0083 appressoria were not variable like that in C. excelsum-altitudum and C. tropicicola. Here we introduced strains MFLUCC 14-0077, MFLUCC 14-0079, MFLUCC 14-0082 and MFLUCC 14-0083 and MFLUCC-14-0085 isolated from stems and roots of Dendrobium sp. 1 as Colletotrichum parallelophorum sp.nov.

\section{Colletotrichum citricola F. Huang, L. Cai, K.D. Hyde \& H.Y. Li}

Figure 7

Description. Asexual morph on CMA. Vegetative hyphae $3.1 \pm 1.1 \mu \mathrm{m} \operatorname{diam}(\mathrm{N}=20)$, smooth-walled, septate, branched, hyaline. Chlamydospores globose, hyaline. Conidiomata ovoid, orange. Setae (51.8-) 54.1-67.8 (-68.5) $\times(2.3-)$ 2.4-5.8 (-7.2) $\mu \mathrm{m}$ $(\mathrm{N}=6)$, smooth-walled, 1 or 3-septate, contracted to slightly inflated base, tapering to the apex, apex acute, pale brown to brown. Conidiophores (10.8-) 16.7-25.6 $(-30.6) \times(3.1-) 4-5.3(-5.6) \mu \mathrm{m}(\mathrm{N}=27)$, smooth-walled, septate, hyaline. Conidia (12.5-) 13.4-15 (16.5-) × (5-) 5.9-6.9 (-7.2) $\mu \mathrm{m}(\mathrm{N}=40), \mathrm{L} / \mathrm{W}=2.2$, ellipsoidal, smooth-walled, hyaline.

Sexual morph on CMA. Ascomata (34.5-) 46.4-84.9 (-87.1) × (31.7-) 33.8$46.5(-50.9) \mu \mathrm{m}(\mathrm{N}=5)$, globose, ostiolate, clustered, pale brown to dark brown. Peridium 1.7-5.8 $\mu \mathrm{m}$ thick, composed of pale to medium brown, flattened, angular cells. Ascogenous hyphae hyaline, smooth-walled. Asci (41.3-) 49.4-65 (-71.6) × (8.3-) 9.5-12.9 (-14.3) $\mu \mathrm{m}(\mathrm{N}=36)$, cylindrical, unitunicate, straight or curved, 8-spored. Ascospores (14.4-) 14.8-17.5 (-19.3) × (5.4-) 5.7-7.1 (-7.6) $\mu \mathrm{m}(\mathrm{N}=25), \mathrm{L} / \mathrm{W}=2.5$, uni-or bi-seriately, smooth-walled, hyaline, fusiform or one end slightly rounded, with a single guttule in the middle. 

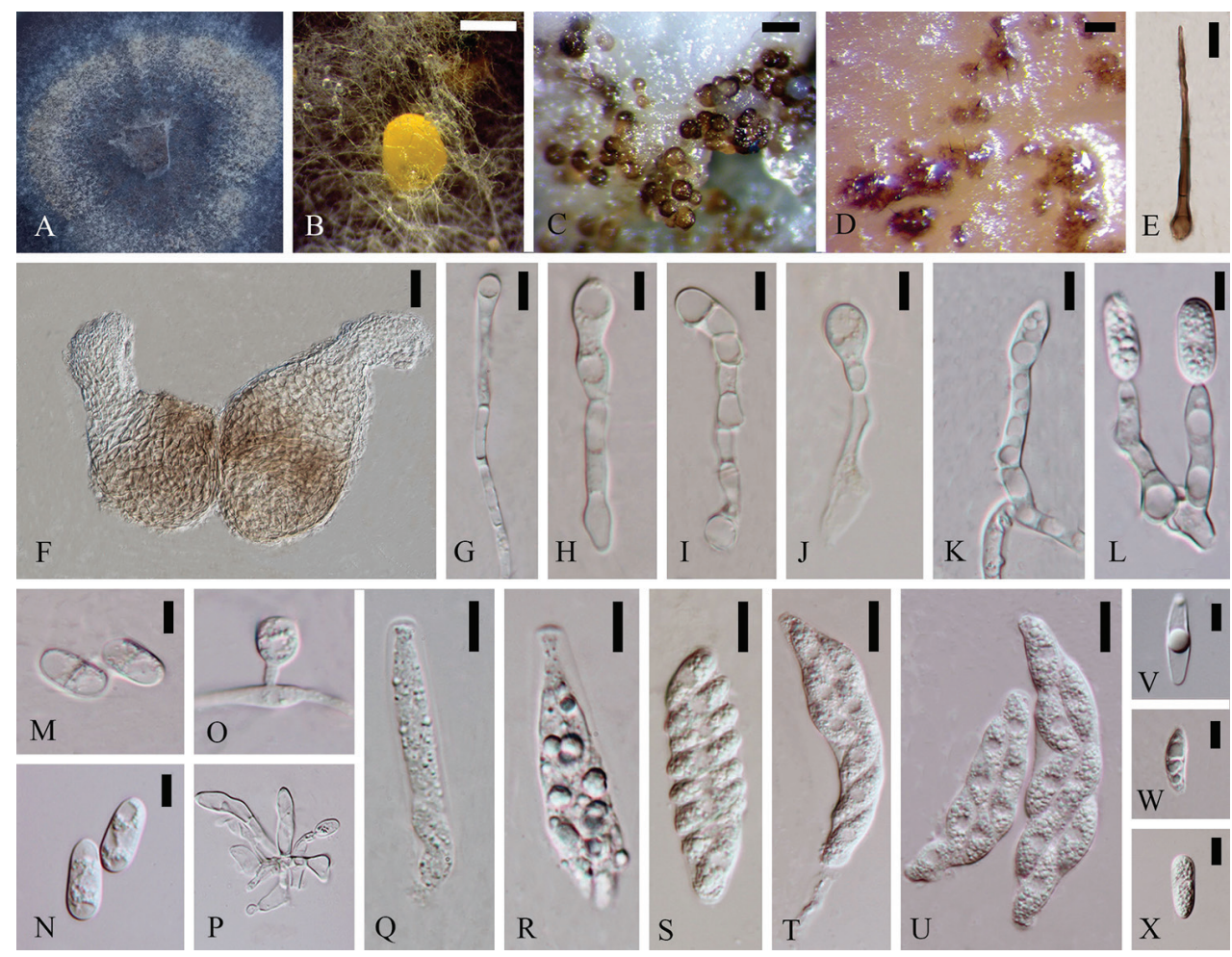

Figure 7. Colletotrichum citricola. A Colony B Conidiomata C Fruiting bodies $\mathbf{D}$ Fruiting body with setae E Setae $\mathbf{F}$ Ascomata G-L Conidiophores $\mathbf{M}, \mathbf{N}$ Conidia $\mathbf{O}$ Chlamydospore $\mathbf{P}-\mathbf{U}$ Young asci $\mathbf{V}-\mathbf{X}$ Ascospores. Scale bars: $500 \mu \mathrm{m}$ (B), $200 \mu \mathrm{m}(\mathbf{C}), 10 \mu \mathrm{m}(\mathbf{E}-\mathbf{F}), 5 \mu \mathrm{m}(\mathbf{G}), 5 \mu \mathrm{m}(\mathbf{M}-\mathbf{N}), 10 \mu \mathrm{m}(\mathbf{Q}-\mathbf{U}), 5 \mu \mathrm{m}(\mathbf{V}-\mathbf{X})$.

Cultures on CMA flat with entire margin. Growth rate: $0.6 \mathrm{~cm} /$ day, with18-days for sporulation. Fluffy, pale mycelia float on the dark scarlet pigment medium, reverse dark brown. Perithecia gregarious. Orange acervuli and ascomata in mass form thick globules.

Notes. Strains MFLUCC 14-0129 and MFLUCC 14-0131 had similar sequence data, cultures and conidia. There were $5 \mathrm{bp}$ and $7 \mathrm{bp}$ difference between the strains and Colletotrichum camelliae-japonicae and C. citricola respectively. ITS sequence is 99\% identity with unpublished C. boninense strain LD3-8-1 isolated from strawberry in China (Unpublished). Blastn searches sequences results in GAPDH (GenBank KC293736) and TUB2 (GenBank KC293656) sequences of C. citricola strain SXC 151 as mention above. ACT sequence is closest to C. karstii strain 42a (GenBank KT122921) isolated from Coffea arabica in Mexico (Cristobal-Martinez et al. 2016). All morphological characteristics of the two strains were nearly the same as the protologue of C. citricola. Therefore, we name strains MFLUCC 14-0129 and MFLUCC 14-0131 as C. citricola. When compared with C. camelliae-japonicae (conidia: 11-14.5 $\times 5-6.5 \mu \mathrm{m}$, mean $\pm \mathrm{SD}=12.5 \pm 0.8 \times 5.5 \pm 0.3 \mu \mathrm{m}, \mathrm{L} / \mathrm{W}=1.5$; ascospores: $13.5-18.5$ $\times 4-5.5 \mu \mathrm{m}$, mean $\pm \mathrm{SD}=16.5 \pm 1.1 \times 5 \pm 0.4 \mu \mathrm{m}, \mathrm{L} / \mathrm{W}=3.3$ ), strains MFLUCC 140129 and MFLUCC 14-0131 have shorter conidia and wider ascospores. 


\section{Colletotrichum fructicola Prihastuti, L. Cai \& K.D. Hyde}

Figure 8

Description. Asexual morph formed on CMA. Vegetative hyphae 2.6-5 $\mu \mathrm{m}$ diam $(\mathrm{N}=20)$, smooth-walled, septate, branched, hyaline. Appressoria and chlamydospores not observed. Conidiomata $500 \times 400 \mu \mathrm{m}(\mathrm{N}=3)$, clustered, sub-globose, smooth-walled, orange. Conidiophores rare, septate, hyaline. Conidia (12.8-) 13.8-16.6 (-18.6) $\times(2.7-$ ) 3.5-7.8 (-16) $\mu \mathrm{m}(\mathrm{N}=21), \mathrm{L} / \mathrm{W}=2.9$, ellipsoidal, smooth-walled, septate, hyaline.

Sexual morph forming on CMA. Ascomata globose, pale brown to dark brown. Peridium (131.9-) 138.4-163.6 (-171.5) × (120.9-) 123.6-142.1 (-143.2) $\mu \mathrm{m}(\mathrm{N}=4)$, composed of medium brown, flattened, angular cells. Setae (53-) 57.2-73.1 (-83.3) $\times(3.4-) 3.5-4(-4.1) \mu \mathrm{m}(\mathrm{N}=6)$, grow on the fruiting body, 2-septate, smooth-walled, contracted at the base, apex slightly rounded, brown to dark brown. Asci (57.6-) 61.2-82.6 (-94.3) × (8.7-) 9.3-13.3 (-15.8) $\mu \mathrm{m}(\mathrm{N}=12)$, cylindrical, unitunicate, 8-spored. Ascospores (10-) 12-20 (-20.9) × (3.6-) 4.1-5.2 (-5.3) $\mu \mathrm{m}(\mathrm{N}=10), \mathrm{L} / \mathrm{W}$ $=3.4$, ellipsoidal to reniform, somewhat fusiform or acute both ends, 1 to 4 guttules, uni-to bi-seriate, smooth-walled, hyaline.

Cultures on CMA flat with slight serrated margin. Growth rate: $0.9 \mathrm{~cm} /$ day, with 14-days for sporulation. Cottony, light brown to white from middle to the margin, reverse white to light brown with black spots. Ascomata gregarious and/or isolated. Acervuli and ascomata sometimes gregarious.
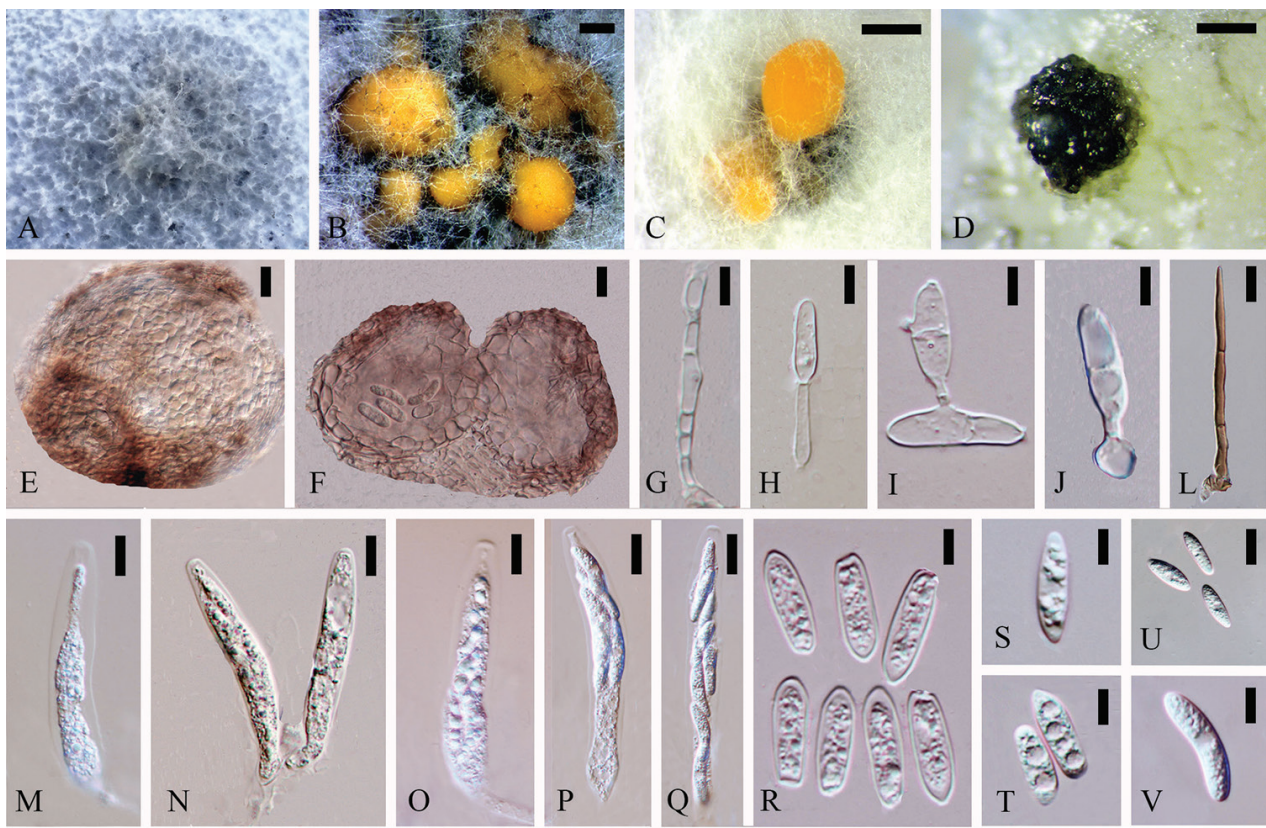

Figure 8. Colletotrichum fructicola. A Colony B Conidiomata and ascomata C, D Conidiomata E, F Ascomata G-J Conidiophores L Setae M-Q Asci R-V Ascospores Scale bars: $500 \mu \mathrm{m}$ (B-D), $20 \mu \mathrm{m}$ (E, F), $5 \mu \mathrm{m}(\mathbf{G}-\mathbf{J}), 10 \mu \mathrm{m}(\mathbf{L}), 10 \mu \mathrm{m}(\mathbf{M}-\mathbf{Q}), 5 \mu \mathrm{m}(\mathbf{R}-\mathbf{V})$. 
Notes. Strains MFLUCC 14-0087, MFLUCC 14-0148 and MFLUCC 150262 had the identical sequences to Colletotrichum fructicola. The ITS and GAPDH sequences of them $100 \%$ match with many different unpublished species. Blastn researches with ACT sequence of them results in $99 \%$ identity with the ex-holotype culture of C. fructicola strain ICMP 18581 (GenBank JX009501) isolated from Coffea arabica in Thailand (Weir et al. 2012), which we involved it in phylogenetic analysis. TUB2 sequences of them are 99\% identity with $C$. boninense strain CBS 125502 (GenBank KJ955336) as mentioned above. Their ascomata, conidia, asci and ascospores were also similar. Conidia were the same size as the ex-type strain of the pathogen Colletotrichum fructicola $(9.7-14 \times 3-4.3 \mu \mathrm{m})$ found in coffee berries (Prihastuti et al. 2009). However, ascomata were much smaller and asci as well as ascospores were much larger than the ex-type from coffee berries. In the protologue, C. fructicola was introduced with ascomata as $345.67 \pm 36.83 \times 431.33 \pm 69.89$ $\mu \mathrm{m}$, asci as $41.22 \pm 7.02 \times 7.61 \pm 0.58 \mu \mathrm{m}$ and ascospores as $11.91 \pm 1.38 \times 3.32$ $\pm 0.35 \mu \mathrm{m}$. Here we name strains MFLUCC 14-0087, MFLUCC 14-0148 and MFLUCC 15-0262 isolated from leaves of Dendrobium sp.1 and Dendrobium sp.3, root of Dendrobium sp.2 as Colletotrichum fructicola.

\section{Colletotrichum jiangxiense F. Liu \& L. Cai}

Figure 9

Description. Sexual morph not observed.

Sexual morph not observed. Asexual morph on PDA. Vegetative hyphae 1.3-2.1 $\mu \mathrm{m}$ diam $(\mathrm{N}=20)$, smooth-walled, septate, branched, hyaline. Setae and chlamydospores not observed. Conidiophores (12.7-) 13.5-21.4 (-23.4) × (1.9-) 2-3 (-3.2) $\mu \mathrm{m}(\mathrm{N}=8)$, branched, hyaline. Conidia (8.6-) 9-12.4 (-13.2) $\times(3.5-)$ 3.6-4.4 (-4.5) $\mu \mathrm{m}(\mathrm{N}=4), \mathrm{L} / \mathrm{W}=2.6$, ellipsoidal to cylindrical, smooth-walled, aseptate, one end more blunt than the other end, hyaline.

Cultures on PDA flat with entire margin. Growth rate: $0.4 \mathrm{~cm} /$ day, with 18 days for sporulation. Aerial mycelia dense, cottony, pale to light brown, with brown outline ring close to the edge, mycelia in the middle dark brown, reverse white to light brown.

Notes. Strains MFLUCC 14-0091 and MFLUCC 14-0092 were the same species as they grouped with high support (98ML/1.0BI/87MP). They formed a very close clade with the pathogen $C$. jiangxiense isolated from Camellia. However, different media were used in these two studies. Blastn researches with ITS sequences results in 100\% identity with C. gloeosporioides strain SS1-MS1 (GenBank KP900279) isolated from Huperzia serrate in China (Wang et al. 2016). GAPDH, ACT and TUB2 sequences of MFLUCC 14-0091 and MFLUCC 14-0092 are closest to C. kahawae subsp. ciggaro strain ICMP 18534 (GenBank JX009904) with 98\% identity isolated from Kunzea ericoides in New Zealand, 99\% identity with strain ICMP 12952 (GenBank JX009431) isolated from Persea Americana in New Zealand, and 99\% identity with strain CO22-1 (GenBank KJ001124) isolated from Rubus glaucus in Colombia respectively (Weir et al. 2012; 

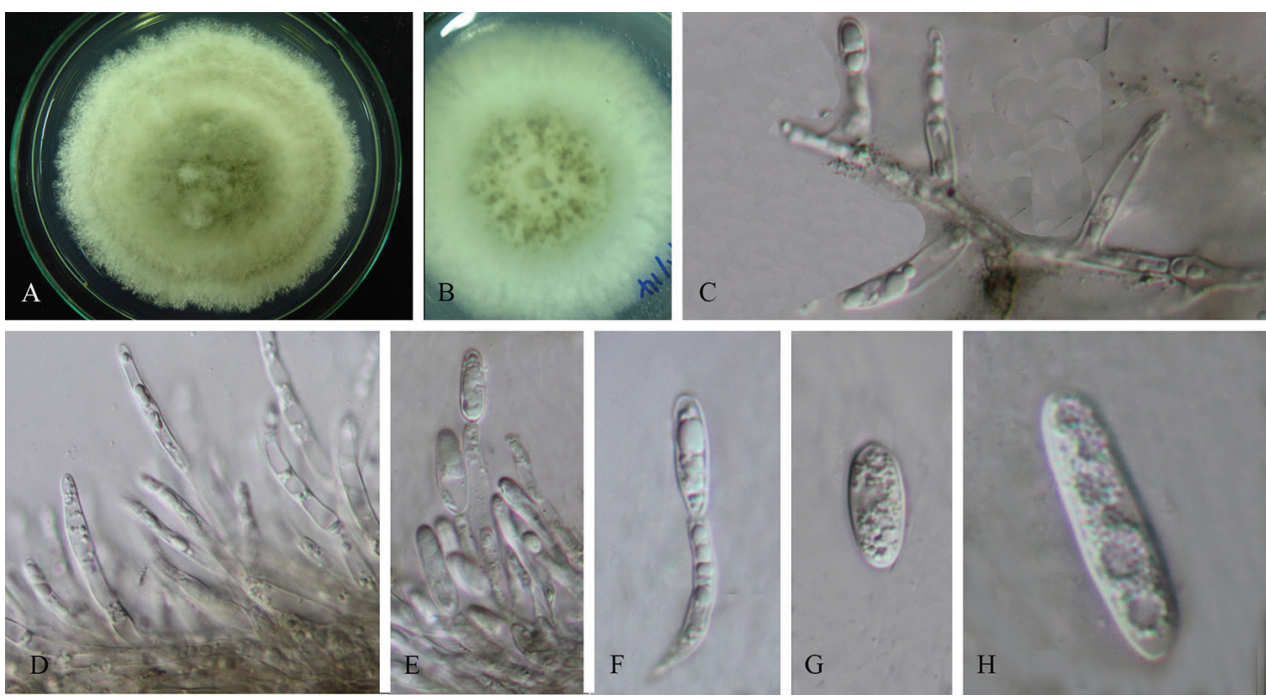

Figure 9. Colletotrichum jiangxiense. A Colony B Colony from below C-F Conidiophores G-H Conidia. Scale bars: $5 \mu \mathrm{m}(\mathbf{C}-\mathbf{F}), 2.5 \mu \mathrm{m}(\mathbf{G}-\mathbf{H})$.

Afanador-Kafuri et al. 2014). Conidia size reported for C. jiangxiense was $15.2 \pm 1 \times$ $5.2 \pm 0.4 \mu \mathrm{m}$, which was larger and faster growing than the strains isolated in this study. There were 5bp differences between strain MFLUCC 14-0091 and C. jiangxiense. Here we name both of isolates from leaves of Dendrobium sp.1 as C. jiangxiense.

\section{Colletotrichum orchidophilum Damm, P.F. Cannon \& Crous}

Figure 10

Description. Sexual morph not observed.

Sexual morph not observed. Asexual morph on SDA. Vegetative hyphae 1.9-5.4 $\mu \mathrm{m}$ diam, smooth-walled, septate, branched, hyaline to pale brown. Chlamydospores not observed. Appressoria brown, smooth-walled. Conidiomata superficial or under mycelia, smooth-walled, $200 \times 300 \mu \mathrm{m}$, black. Conidiophores smooth-walled, branched or unbranched, hyaline. Conidiophores and appressoria rare. Conidia (9.6-) 11.7-14.1 (-14.7) × (2.9-) 3.5-4.4 (-4.8) $\mu \mathrm{m}, \mathrm{L} / \mathrm{W}=3.3$, cylindrical, straight, with 1 to 4 guttules, one end somewhat acute, hyaline.

Cultures on SDA flat with entire margin. Growth rate: $0.44 \mathrm{~cm} /$ day, with nearly 20-days for sporulation. White with dark green mycelia around the middle, white edge, reverse white. Cultures on PDA flat with entire margin. Growth rate: $0.45 \mathrm{~cm} /$ day, with 30-days for sporulation. Fluffy, white, reverse light brown. Acervuli in mass black, irregular, asymmetrical, merging in media.

Notes. Strains MFLUCC-14-0161 and MFLUCC-14-0162 belong to a single species as they have similar conidia, cultures and the nearly identical sequence data. The 

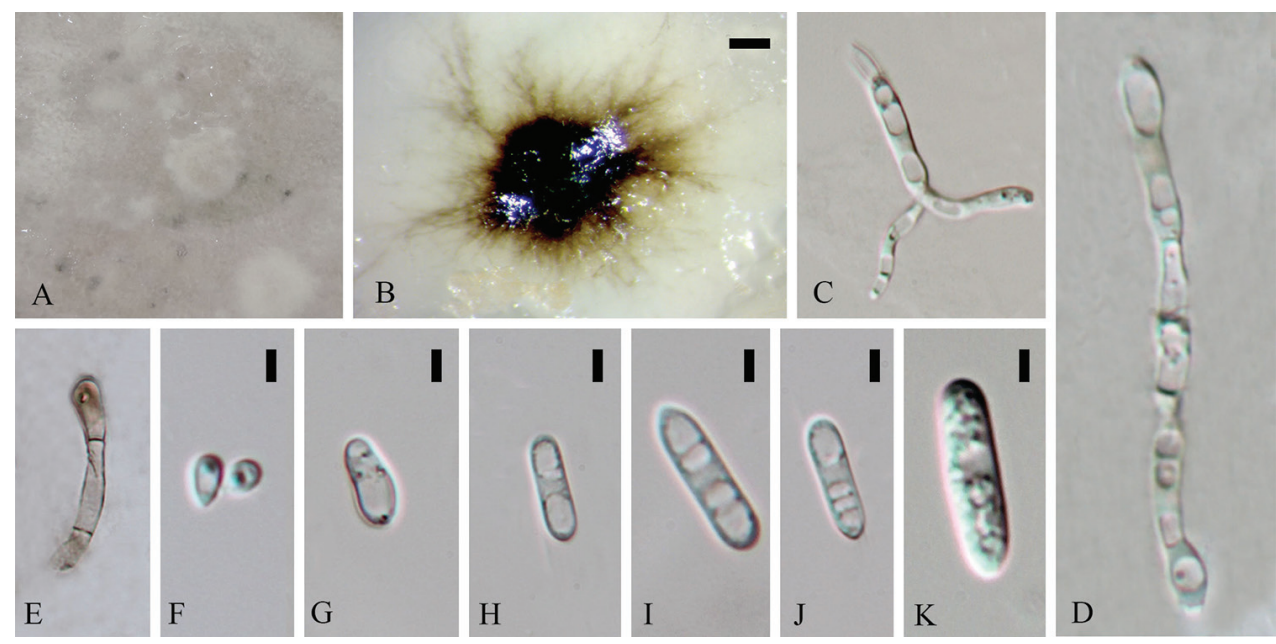

Figure 10. Colletotrichum orchidophilum. A Colony B Fruiting body C-D Conidiophores E Appressoria F-K Conidia. Scale bars: $200 \mu \mathrm{m}$ (B), $5 \mu \mathrm{m}$ (F-K).

support values of 100/1.00/100 totally grouped them with C. orchidophilum and their branch lengths are slightly different. Blastn researches sequences of MFLUCC 14-0161 and MFLUCC 14-0162 results in 99\% identity with ITS (GenBank NR111729), GAPDH (GenBank JQ948481) and ACT (GenBank JQ949472) sequences of exholotype culture of C. orchidophilum strain CBS 632.80 isolated from Dendrobium sp. in USA (Damm et al. 2012). TUB2 sequence is $99 \%$ identity with pathogenic $C$. fructicola strain AV24 (GenBank KX786459) isolated from grapevine shoots in Brazil (Santos et al. 2018) and C. gloeosporioides strain TL-2 (GenBank KC913205) isolated from Camellia sinensis in China (Guo et al. 2014). Because no conidiophores were detected in culture, no measurement for the conidiophores could be given. In this study, strains MFLUCC 14-0161 and MFLUCC 14-0162 of C. orchidophilum were isolated from leaves of $D$. harveyanum.

\section{Colletotrichum boninense Moriwaki, Toy. Sato \& Tsukib.}

For an illustrated description please refer Damm et al. (2012a).

Notes. Strains MFLUCC 14-0086, MFLUCC 14-0124 and MFLUCC 15-0261 grouped with $C$. boninense and MFLUCC 14-0128. All have very similar sequences as those as the ex-type of with $C$. boninense (only $2 \mathrm{bp}$ difference), while there was 11 base pair deviations between these strains and Colletotrichum doitungense sp. nov. Blastn researches with ITS sequences of them result in $100 \%$ identity with ITS sequence of endophytic C. boninense strain SL-ML18 (GenBank KP900269) isolated from $\mathrm{Hu}$ perzia serrate in China (Wang et al. 2016) and strain CGMCC 3.15168 (GenBank KC244158) as mentioned above. GAPDH and ACT sequences of them are 97\% identity with C. boninense CGMCC 3.15168 (GenBank KC843491) and 100\% identity 
with C. fructicola strain 1104-7 (GenBank KX885159) isoalted from Malus domestica in China (Liang et al. 2017). TUB2 blastn result are $99 \%$ identity with $C$. fructicola strain AV24 (GenBank KX786459) and C. gloeosporioides strain TL-2 (GenBank KC913205) as mentioned above. Here we identify these three strains isolated from leaves of $D$. catenatum and Dendrobium sp.1, stem of D. sp.2 respectively as Colletotrichum boninense.

\section{Colletotrichum sp. indet}

Notes. Strain MFLUCC 14-0120 failed to sporulate and lacks a complete morphological description. It formed a single branch close to C. camelliae-japonicae, MFLUCC 14-0129 / MFLUCC 14-0131 with 67ML/1.00BI/62MP support. There were 15bp and 11 bp differences mainly in the ACT gene region among MFLUCC 14-0120 and C. camelliae-japonicae, MFLUCC 14-0129/MFLUCC 14-0131 respectively. ITS sequence blastn of MFLUCC 14-0120 showed many different kinds of species with 99\% identity. Blastn searches with GAPDH (GenBank KC293736) and TUB2 (GenBank KC293656) sequences result in 99\% identity with C. citricola strain SCX 151 as mentioned above. The ACT of MFLUCC-14-0120 is $98 \%$ identity with C. boninense strain CBS 125502 (GenBank KJ954462) as mentioned above. Here we listed it as an unidentified species.

\section{Discussion}

\section{Colletotrichum species associated with orchid species}

Many Colletotrichum species have been isolated from Orchidaceae plants sampled in China in previous studies (e.g. Yang et al. 2011; Chen et al. 2012; Tao et al. 2008, 2013). Eighteen Colletotrichum species have been reported from these studies. For example, Colletotrichum beeveri isolated from Pleione bulbocodioides; C. bletillum and C. caudasporum isolated from Bletilla ochracea; C. oncidii isolated from Oncidium sp. (Yang et al. 2011; Damm et al. 2012a; Tao et al. 2013). The present study is the first to report endophytic fungi from Dendrobium spp. in Thailand combining both multi-loci sequence data and morphological characteristics. Colletotrichum species in this study were diverse and present in every Dendrobium sample collected from all sites. Therefore, we conclude that Orchidaceae plants are rich source of endophytic Colletotrichum species.

\section{Methods affecting the identification}

Hyde and Zhang (2008) and Hyde et al. (2009b) suggested that nucleotide sequence data of holotypes or epitypes is essential for analysing phylogenetic relationships among Colletotrichum species. A polyphasic method combining morphological characteristics 
and molecular phylogenetics has been applied to define and re-order species in this genus (Cai et al. 2009; Hyde et al. 2009; Damm et al. 2012a, b, c; Jayawardena et al. 2016a, b).

We found some differences in the Colletotrichum gloeosporioides species complex backbone tree as compared to that constructed with more genes in Weir et al (2012), Udayanga et al (2013) and Jayawardena et al. (2016a). Colletotrichum jiangxiense clusters with C. rhexiae rather than $C$. kahawae. $C$. fructicola is closer to $C$. siamense rather than $C$. nupharicola. The genes CHS-1 and HIS3 were not involved in this study and may be responsible for the differences. Actually CHS-1 and HIS3 could resolve species in sevaral other species complexes of Colletotrichum (Jayawardena et al. 2016a). However, the combination of ApMat and GS turned out to be the most effective genes in species resolution in the Colletotrichum gloeosporioides species complex (Liu et al. 2015). Our study is the first to use multiple gene sequences to analyse fungal endophytes from Dendrobium orchids.

\section{Relationship between Colletotrichum and Dendrobium}

Few species identified in this study showed host-specificity. Nevertheless, this study provides evidence that $C$. orchidophilum colonizes a wide range of hosts in Orchidaceae (Damm et al. 2012b). In addition, we found that leaves contained higher numbers of Colletotrichum species (11 strains from leaves) than other parts ( 4 strains from roots and 7 strains from stems). All Dendrobium leaves in this study were colonized by Colletotrichum strains. Our results are similar to those of Chen et al. (2011) who isolated more Colletotrichum species from stems and leaves of Dendrobium species than that from roots.

The majority of Colletotrichum species isolated from Dendrobium species in this study were fungal endophytes. This was also reported by Chen et al. (2011) and Yuan et al. (2009). The most common fungal endophytes in leaves of Lepanthes rupestris (Orchidaceae) sampled in a Puerto Rican forest were a Colletotrichum species which showed antagonism against other fungal taxa (Bayman et al. 2002). Most Colletotrichum species have been identified as plant pathogens living a hemibiotrophic life strategy, they adopt a biotrophic phase at an early stage and switch to a necrotrophic phase later (Damm et al. 2010; Cannon et al. 2012).

Here we speculate that most isolates in this study might be latent pathogens (Photita et al. 2004), since in the phylogenies, they were nested with pathogenic strains or have previously been reported to cause plant diseases (Tao et al. 2013, Hou et al 2016). Colletotrichum jiangxiense was isolated as a pathogen from leaf lesions of Camellia sp. (Liu et al. 2015). Colletotrichum boninense was reported as an anthracnose causing agent from Dendrobium kingianum in Japan (Moriwaki et al. 2003).

\section{Acknowledgements}

This work was funded by the grants of National Natural Science Foundation of China (Grants Nos. $31670027 \& 31460011$ \& 30870009) and the Agricultural Science and 
Technology Foundation of Guizhou Province, China (Grant No. NY[2013]3042). We sincerely acknowledge great help from Santi Watthana on identification of orchids collected in Thailand.

\section{References}

Altschul SF, Madden TL, Schäffer AA, Zhang J, Zhang Z, Miller W, Lipman DJ (1997) Gapped BLAST and PSI-BLAST: a new generation of protein database search programs. Nucleic Acids Research 25: 3389-3402. https://doi.org/10.1093/nar/25.17.3389

Bailey JA, O'Connell RJ, Pring RJ, Nash C (1992) Infection strategies of Colletotrichum species. In: Bailey JA, Jeger MJ (Eds) Biology, Pathology and Control. CAB, International Press, Wallingford, 88-120.

Bayman P, Gonzalez EJ, Fumero JJ, Tremblay RL (2002) Are fungi necessary? How fungicides affect growth and survival of the orchid Lepanthes rupestris in the field. Journal of Ecology 90(6): 1002-1008. https://doi.org/10.1046/j.1365-2745.2002.00733.x

Bulpitt CJ, Li Y, Bulpitt PF, Wang J (2007) The use of orchids in Chinese medicine. Journal of the Royal Society of Medicine 100(12): 558-563. https://doi. org/10.1177/0141076807100012014

Cannon PF, Damm U, Johnston PR, Weir BS (2012) Colletotrichum-current status and future directions. Studies in Mycology 73: 181-213. https://doi.org/10.3114/sim0014

China Plant Specialist Group (2004) Dendrobium catenatum. The IUCN red list of threatened species e.T46665A11074270. http://dx.doi.org/10.2305/IUCN.UK.RLTS. T46665A11074270.en

Chen J, Hu KX, Hou XQ, Guo SX (2011) Endophytic fungi assemblages from 10 Dendrobium medicinal plants (Orchidaceae). World Journal of Microbiology and Biotechnology 27(5): 1009-1016. https://doi.org/10.1007/s11274-010-0544-y

Crouch JA, Clarke BB, White JrJF, Hillman BI (2009) Systematic analysis of the falcate-spored graminicolous Colletotrichum and a description of six new species from warm season grasses. Mycologia 101: 717-732. https://doi.org/10.3852/08-230

Curry KJ, Abril M, Avant JB, Smith BJ (2002) Strawberry anthracnose: Histopathology of Colletotrichum acutatum and C. fragariae. Phytopathology 92(10): 1055-1063. https:// doi.org/10.1094/PHYTO.2002.92.10.1055

Damm U, Baroncelli R, Cai L, Kubo Y, O’Connell R, Weir B, Yoshino K, Cannon PF (2010) Colletotrichum: species, ecology and interactions. IMA fungus 1(2): 161-165. https://doi. org/10.5598/imafungus.2010.01.02.08

Damm U, Cannon PF, Liu F (2013) The Colletotrichum orbiculare species complex: important pathogens of field and weeds. Fungal Diversity 61: 29-59. https://doi.org/10.1007/ s13225-013-0255-4

Damm U, Cannon PF, Woudenberg JHC, Johnston PR, Weir BS, Tan YP, Shivas RG, Crous PW (2012a) The Colletotrichum boninense species complex. Studies in Mycology 73: 1-36. https://doi.org/10.3114/sim0002

Damm U, Cannon PF, Woudenberg JHC, Crous PW (2012b) The Colletotrichum acutatum species complex. Studies in Mycology 73: 37-113. https://doi.org/10.3114/sim0010 
Damm U, O'Connell RJ, Groenewald JZ, Crous PW (2014) The Colletotrichum destructivum species complex - hemibiotrophic pathogens of forage and field crops. Studies in Mycology 79: 49-84. https://doi.org/10.1016/j.simyco.2014.09.003

Dean R, Van Kan JAL, Pretorius ZA, Hammond-Kosack KE, Di Pietro A, Spanu PD, Rudd JJ, Dickman M, Kahmann R, Ellis J, Foster GD (2012) The Top 10 fungal pathogens in molecular plant pathology. Molecular Plant Pathology 13: 414-430. https://doi.org/10.1111/ j.1364-3703.2011.00783.x

Diao YZ, Zhang C, Liu F, Wang WZ, Liu L, Cai L, Liu XL (2017) Colletotrichum species causing anthracnose disease of chili in China. Persoonia 38: 20-37. https://doi. org/10.3767/003158517X692788

Ding G, Li X, Ding X, Qian L (2009) Genetic diversity across natural populations of Dendrobium catenatum, the endangered medicinal herb endemic to China, revealed by ISSR and RAPD markers. Russian Journal of Genetics 45(3): 327-334. https://doi.org/10.1134/ S1022795409030119

Gan P, Nakata N, Suzuki T, Shirasu K (2017) Markers to differentiate species of anthracnose fungi identify Colletotrichum fructicola as the predominant virulent species in strawberry plants in Chiba Prefecture of Japan. Journal of General Plant Pathology 83(1): 14-22. https://doi.org/10.1007/s10327-016-0689-0

Gu S, Ding XY, Wang Y et al. (2007) Isolation and characterization of microsatellite markers in Dendrobium officinale, an endangered herb endemic to China. Molecular Ecology Resources 7(6): 1166-1168. https://doi.org/10.1111/j.1471-8286.2007.01817.x

Guo M, Pan YM, Dai YL, Gao ZM (2014) First report of brown blight disease caused by Colletotrichum gloeosporioides on Camellia sinensis in Anhui Province, China. Plant Disease 98(2): 284-284. https://doi.org/10.1094/PDIS-08-13-0896-PDN

Hall TA (1999) BioEdit: a user-friendly biological sequence alignment editor and analysis program for Windows 95/98/NT. Nucleic Acids Symposium Series 41: 95-98.

Hongsanan S, Maharachchikumbura SSN, Hyde KD, Samarakoon MC, Jeewon R, Zhao Q, Al-Sadi AM, Bahkali AH (2017) An updated phylogeny of Sordariomycetes based on phylogenetic and molecular clock evidence. Fungal Diversity 84(1): 25-41. https://doi. org/10.1007/s13225-017-0384-2

Hou LW, Liu F, Duan WJ, Cai L (2016) Colletotrichum aracearum and C. camelliae-japonicae, two holomorphic new species from China and Japan. Mycosphere 7: 1111-1123. https:// doi.org/10.5943/mycosphere/si/2c/4

Hyde KD, Cai L, Cannon PF, Cannon PF, Crouch JA, Crous PW, Damm U, Goodwin PH, Chen H, Johnston PR, Jones EB, Liu ZY (2009a) Colletotrichum names in current use. Fungal Diversity 39(1): 147-182.

Hyde KD, Cai L, McKenzie EHC, Yang YL, Zhang JZ, Prihastuti H (2009b) Colletotrichum: a catalogue of confusion. Fungal Diversity 39: 1-17.

Hyde KD, Abd-Elsalam K, Cai L (2010) Morphology: still essential in a molecular world. Mycotaxon 114(1): 439-451. https://doi.org/10.5248/114.439

Hyde KD, Nilsson RH, Alias SA, Ariyawansa HA, Blair JE, Cai L, de Cock AW, Dissanayake AJ, Glockling SL, Goonasekara ID, Gorczak M (2014) One stop shop: backbones trees for important pytopathogenic genera: I. Fungal Diversity 67: 21-125. https://doi. org/10.1007/s13225-014-0298-1 
Huang F, Chen GQ, Hou X, Fu YS, Cai L, Hyde KD, Li HY (2013) Colletotrichum species associated with cultivated citrus in China. Fungal Diversity 61(1): 61-74. https://doi. org/10.1007/s13225-013-0232-y

Jadrane I, Kornievsky M, Desjardin DE, He ZH, Cai L, Hyde K (2012) First report of flower anthracnose caused by Colletotrichum karstii in white Phalaenopsis orchids in the United States. European Journal of Plant Pathology 146(3): 465-481. https://doi.org/10.1094/ PDIS-04-12-0360-PDN

Jayawardena RS, Hyde KD, Damm U, Cai L, Liu M, Li XH, Zhang W, Zhao WS, Yan JY (2016a) Notes on currently accepted species of Colletotrichum. Mycosphere 7: 1192-1260. https://doi.org/10.5943/mycosphere/si/2c/9

Jayawardena RS, Cai L, McKenzie EHC, Li XH, Liu M, Yan JY (2016b) Why is it important to correctly name Colletotrichum species? Mycosphere 7(8): 1076-1092. https://doi. org/10.5943/mycosphere/si/2c/1

Jeewon R, Hyde KD (2016) Establishing species boundaries and new taxa among fungi: recommendations to resolve taxonomic ambiguities. Mycosphere 7(11): 1669-1677. https://doi. org/10.5943/mycosphere/7/11/4

Jiang J, Zhai H, Li H, Wang Z, Chen Y, Hong N, Wang G, Chofong GN, Xu W (2014) Identification and characterization of Colletotrichum fructicola causing black spots on young fruits related to bitter rot of pear (Pyrus bretschneideri Rehd.) in China. Crop Protection 58: 41-48. https://doi.org/10.1016/j.cropro.2014.01.003

Katoh K, Toh H (2008) Recent developments in the MAFFT multiple sequence alignment program. Brief Bioinform 9: 276-285. https://doi.org/10.1093/bib/bbn013

Kalyaanamoorthy S, Minh BQ, Wong TKF, von Haeseler A, Jermiin LS (2017) ModelFinder: Fast Model Selection for Accurate Phylogenetic Estimates, Nature Methods 14: 587-589. https://doi.org/10.1038/nmeth.4285

Kleemann J, Rincon-RiveraLJ, Takahara H, Neumann U, van Themaat EV, van der Does HC, Hacquard S, Stüber K, Will I, Schmalenbach W, Schmelzer E (2012) Sequential delivery of host-induced virulence effectors by appressoria and intracellular hyphae of the phytopathogen Colletotrichum higginsianum. PLoS pathogens 8(4): pe1002643. https://doi. org/10.1371/journal.ppat.1002643

Li H, Zhou GY, Liu JA, Xu J (2016) Population genetic analyses of the fungal pathogen Colletotrichum fructicola on tea-oil trees in China. PloS one 11(6): e0156841. https://doi. org/10.1371/journal.pone.0156841

Li HN, Jiang JJ, Hong N, Wang GP, Xu WX (2016) First report of Colletotrichum fructicola causing bitter rot of pear (Pyrus bretschneideri) in China. Plant Disease 100(6): 1235.

Liang X, Tian X, Liu W, Wei T, Wang W, Dong Q, Wang B, Meng Y, Zhang R, Gleason ML (2017) Comparative analysis of the mitochondrial genomes of Colletotrichum gloeosporioides sensu lato: insights into the evolution of a fungal species complex interacting with diverse plants. BMC Genomics 18(1): 171. https://doi.org/10.1186/s12864-016-3480-x

Lichtemberg PSF, Moral J, Morgan DP, Felts DG, Sanders RD, Michailides TJ (2017) First report of anthracnose caused by Colletotrichum fioriniae and C. karstii in California Pistachio Orchards. Plant Disease 101(7): 1320. https://doi.org/10.1094/PDIS-0117-0144-PDN 
Lin Y, Li J, Li B, He T, Chun Z (2011) Effects of light quality on growth and development of protocorm - like bodies of Dendrobium catenatum in vitro. Plant Cell, Tissue and Organ Culture 105(3): 329-335. https://doi.org/10.1007/s11240-010-9871-9

Lin Y, Wang F, Yang L, Chun Z, Bao JK, Zhang GL (2013) Anti-inflammatory phenanthrene derivatives from stems of Dendrobium denneanum. Phytochemistry 95: 242-251. https:// doi.org/10.1016/j.phytochem.2013.08.008

Liu F, Damm U, Cai L, Crous PW (2013) Species of the Colletotrichum gloeosporioides, complex associated with anthracnose diseases of Proteaceae. Fungal Diversity 61(1): 89-105. https://doi.org/10.1007/s13225-013-0249-2

Liu F, Cai L, Crous PW, Damm U (2014) The Colletotrichum gigasporum species complex. Persoonia - Molecular Phylogeny and Evolution of Fungi 33(1): 83-97. https://doi. org/10.3767/003158514X684447

Liu F, Weir BS, Damm U, Crous PW, Wang Y, Liu B, Wang M, Zhang M, Cai L (2015) Unravelling Colletotrichum species associated with Camellia: employing ApMat and GS loci to resolve species in the $C$. gloeosporioides complex. Persoonia-Molecular Phylogeny and Evolution of Fungi 35(1): 63-86. https://doi.org/10.3767/003158515X687597

Lu G, Cannon PF, Alex RE, Simmons CM (2004) Diversity and molecular relationships of endophytic Colletotrichum isolates from the Iwokrama Forest Reserve, Guyana. Mycological Research 108: 53-63. https://doi.org/10.1017/S0953756203008906

Ma XY, Kang JC, Nontachaiyapoom S, Wen T, Hyde KD (2015) Non-mycorrhizal endophytic fungi from orchids. Current Science 109(1): 72-87.

Maharachchikumbura SSN, Guo LD, Cai L, Chukeatirote E, Wu WP, Sun X, Crous PW, Bhat DJ, McKenzie EH, Bahkali AH, Hyde KD (2012) A multi - locus backbone tree for Pestalotiopsis with a polyphasic characterization of 14 new species. Fungal Diversity 56(1): 95-129. https://doi.org/10.1007/s13225-012-0198-1

Maharachchikumbura SSN, Hyde KD, Jones EBG, McKenzie EH, Bhat JD, Dayarathne MC, Huang SK, Norphanphoun C, Senanayake IC, Perera RH, Shang QJ (2016) Families of Sordariomycetes. Fungal Diversity 79(1): 1-317. https://doi.org/10.1007/s13225-016-0369-6

Maharachchikumbura SSN, Hyde KD, Jones EBG, McKenzie EH, Huang SK, Abdel-Wahab MA, Daranagama DA, Dayarathne M, D’souza MJ, Goonasekara ID, Hongsanan S (2015) Towards a natural classification and backbone tree for Sordariomycetes. Fungal Diversity 72(1): 199-301. https://doi.org/10.1007/s13225-015-0331-z

Mangunwardoyo W, Suciatmih IG (2011) Frequency of endophytic fungi isolated from Dendrobium crumenatum (Pigeon orchid) and antimicrobial activity. Biodiversitas 13(1): 34-39. https://doi.org/10.13057/biodiv/d130107

Moriwaki J, Sato T, Tsukiboshi T (2003) Morphological and molecular characterization of Colletotrichum boninense sp. nov. from Japan. Mycoscience 44(1): 47-53. https://doi. org/10.1007/S10267-002-0079-7

Mendgen K, Hahn M (2002) Plant infection and the establishment of fungal biotrophy. Trends in plant science 7(8): 352-356. https://doi.org/10.1016/S1360-1385(02)02297-5

NG TB, Liu J, Wong JH, Ye X, Sze SC, Tong Y, Zhang KY (2012) Review of research on Dendrobium, a prized folk medicine. Applied Microbiology and Biotechnology 93(5): 1795-1803. https://doi.org/10.1007/s00253-011-3829-7 
Noireung P, Phoulivong S, Liu F, Cai L, Mckenzie EH, Chukeatirote E, Jones EB, Bahkali AH, Hyde KD (2012) Novel species of Colletotrichum revealed by morphology and molecular analysis. Cryptogamie, Mycologie 33(3): 347-362. https://doi.org/10.7872/crym.v33.iss3.2012.347

Nontachaiyapoom S, Sasirat S, Manoch L (2010) Isolation and identification of Rhizoctonialike fungi from roots of three orchid genera, Paphiopedilum, Dendrobium, and Cymbidium collected in Chiang Rai and Chiang Mai provinces of Thailand. Mycorrhiza 20: 459-471. https://doi.org/10.1007/s00572-010-0297-3

Nylander JA (2004) MrModeltest v2. Program distributed by the author. Evolutionary Biology Centre, Uppsala University. Uppsala, Sweden.

Otero JT, Ackerman JD, Bayman P (2002) Diversity and host specificity of endophytic Rhizoctonia - like fungi from tropical orchids. American Journal of Botany 89: 1852-1858. https://doi.org/10.3732/ajb.89.11.1852

Ping L (2003) Advances in studies on pharmacology of plants from Dendrobium Sw. Chinese Traditional \& Herbal Drugs 36(12): e215-e217.

Photita W, Lumyong S, Lumyong P, McKenzie EH, Hyde KD (2004) Are some endophytes of Musa acuminata latent pathogens. Fungal Diversity 16(1): 131-140.

Prihastuti H, Cai L, Chen H, McKenzie EH, Hyde KD (2009) Characterization of Colletotrichum species associated with coffee berries in northern Thailand. Fungal Diversity 39(1): 89-109.

Prusky D, Plumbley RA (1992) Quiescent infections of Colletotrichum in tropical and subtropical fruit in: Colletotrichum. In: Bailey JA, Jeger MJ (Eds) Biology, Pathology and Control, CABI Press, Wallingford, 289-307.

Radiastuti N, Mutea D, Sumarlin LO (2017) Endophytic Colletrotrichum spp. from Cinchona calisaya Wedd and it's potential quinine production as antibacterial and antimalaria. In: AIP Conference Proceedings 1813(1): 020022.

Redman RS, Dunigan DD, Rodriguez RJ (2001) Fungal symbiosis from mutualism to parasitism: who controls the outcome, host or invader? New Phytologist 151(3): 705-716. https://doi.org/10.1046/j.0028-646x.2001.00210.x

Rojas EI, Rehner SA, Samuels GJ, Van Bael SA, Herre EA, Cannon P, Chen R, Pang J, Wang R, Zhang Y, Peng YQ (2010) Colletotrichum gloeosporioides s.l. associated with Theobroma cacao and other plants in Panama: multilocus phylogenies distinguish pathogen and endophyte clades. Mycologia 102: 1318-1338. https://doi.org/10.3852/09-244

Santos RF, Ciampi-Guillardi M, Amorim L, Massola Júnior NS, Spósito MB (2017) Aetiology of anthracnose on grapevine shoots in Brazil. Plant Pathology Oct 24.

Sharma G, Shenoy BD (2014) Colletotrichum fructicola and C. siamense are involved in chilli anthracnose in India. Archives of Phytopathology and Plant protection 47(10): 11791194. https://doi.org/10.1080/03235408.2013.833749

Shi NN, Du YX, Chen FR, Ruan HC, Yang XJ (2017) First report of leaf spot caused by Colletotrichum fructicola on Japan Fatsia (Fatsia japonica) in Fujian Province in China. Plant Disease 101(8):1552. https://doi.org/10.1094/PDIS-12-16-1720-PDN

Silvestro D, Michalak I (2012) RaxmlGUI: a graphical front-end for RAxML. Organisms Diversity \& Evolution 12(4): 335-337. https://doi.org/10.1007/s13127-011-0056-0

Swofford DL (2002) PAUP* 4.0: phylogenetic analysis using parsimony (* and other methods). Sinauer Associates, Sunderland. 
Tao G, Liu ZY, Hyde KD, Liu XZ, Yu ZN (2009) Whole rDNA analysis reveals novel and endophytic fungi in Bletilla ochracea (Orchidaceae). Fungal Diversity 33: 101-122.

Tao G, Liu ZY, Liu F, Gao YH, Cai L (2013) Endophytic Colletotrichum species from Bletilla ochracea (Orchidaceae) with descriptions of seven new species. Fungal Diversity 61(1): 139-164. https://doi.org/10.1007/s13225-013-0254-5

The Plant List (2013) Version 1.1. Published on the Internet. http://www.theplantlist.org [accessed $1^{\text {st }}$ January]

Udayanga D, Manamgoda DS, Liu X, Chukeatirote E, Hyde KD (2013) What are the common anthracnose pathogens of tropical fruits? Fungal Diversity 61(1): 165-179. https:// doi.org/10.1007/s13225-013-0257-2

Wang H, Fang H, Wang Y, Duan L, Guo S (2011) In situ seed baiting techniques in Dendrobium catenatum Kimuraet Migo and Dendrobium nobile Lindl.: the endangered Chinese endemic Dendrobium (Orchidaceae). World Journal of Microbiology and Biotechnology 27(9): 2051-2059. https://doi.org/10.1007/s11274-011-0667-9

Wang Y, Lai Z, Li XX, Yan RM, Zhang ZB, Yang HL, Zhu D (2016) Isolation, diversity and acetylcholinesterase inhibitory activity of the culturable endophytic fungi harboured in Huperzia serrata from Jinggang Mountain, China. World Journal of Microbiology \& Biotechnology 32(2): 20. https://doi.org/10.1007/s11274-015-1966-3

Weir BS, Johnston PR, Damm U (2012) The Colletotrichum gloeosporioides species complex. Studies in Mycology 73(1): 115. https://doi.org/10.3114/sim0011

Xia L, Liu X, Guo H, Zhang H, Zhu J, Ren F (2012) Partial characterization and immunomodulatory activity of polysaccharides from the stem of Dendrobium officinale (Tie pi shi hu) in vitro. Journal of functional foods 4(1): 294-301. https://doi.org/10.1016/j.jff.2011.12.006

Xia X, Xie Z, Salemi M, Chen L, Wang Y (2003) An index of substitution saturation and its application. Molecular Phylogenetics \& Evolution 26(1): 1. https://doi.org/10.1016/ S1055-7903(02)00326-3

Xing YM, Chen J, Cui JL, Chen XM, Guo SX (2011) Antimicrobial activity and biodiversity of endophytic fungi in Dendrobium devonianum and Dendrobium thyrsiflorum from Vietman. Current microbiology 62(4): 1218- 1224. https://doi.org/10.1007/s00284-010-9848-2

Xu FQ, Xu FC, Hou B, Fan WW, Zi CT, Li Y, Dong FW, Liu YQ, Sheng J, Zuo ZL, Hu JM (2014) Cytotoxic bibenzyl dimers from the stems of Dendrobium fimbriatum Hook. Bioorganic \& Medicinal Chemistry Letters 24(22): 5268-5273. https://doi.org/10.1016/j.bmcl.2014.09.052

Xu JH, Li L, Chen LZ (1995) Studies on the effects of white Dendrobium (Dendrobium candicum) and American ginseng (Panax quinquefolius) on nourishing the Yin and promoting glandular secretion in mice and rabbits. Chinese Traditional Herb Drug 6: 79-80.

Yuan Z, Chen YC, Yang Y (2009) Diverse non-mycorrhizal fungal endophytes inhabiting an epiphytic, medicinal orchid (Dendrobium nobile): estimation and characterization. World Journal of Microbiology and Biotechnology 25(2): 295. https://doi.org/10.1007/s11274-008-9893-1

Yang Y, Cai L, Yu Z, Liu Z, Hyde KD (2011) Colletotrichum species on Orchidaceae in southwest China. Cryptogamie, Mycologie 32(3): 229-253. https://doi.org/10.7872/crym.v32. iss3.2011.229

Yang YL, Liu ZY, Cai L, Hyde KD, Yu ZN, McKenzie EHC (2009) Colletotrichum anthracnose of Amaryllidaceae. Fungal Diversity 39: 123-146. 


\section{Appendix A}

Fungal isolates and sequences of region/genes used in Colletotrichum phylogenetic analysis.

\begin{tabular}{|c|c|c|c|c|c|}
\hline \multirow{2}{*}{ Species } & \multirow{2}{*}{ Isolate $^{\mathrm{a}}$} & \multicolumn{4}{|c|}{ GenBank accession number } \\
\hline & & ITS & GAPDH & ACT & B-tubulin \\
\hline C. acutatum & CBS $128531^{*}$ & JQ005776 & JQ948677 & JQ005839 & JQ005860 \\
\hline C. aeschynomenes & CBS $128532^{*}$ & JX010176 & JX009930 & JX009483 & JX010392 \\
\hline C. alcornii & CBS $128534^{*}$ & JX076858 & - & - & - \\
\hline C. alienum & ICMP $12071^{*}$ & JX010251 & JX010028 & JX009572 & JX010411 \\
\hline C. annellatum & CBS $128536^{*}$ & JQ005222 & JQ005309 & JQ005570 & JQ005656 \\
\hline C. anthrisci & CBS $125334^{*}$ & GU227845 & GU228237 & GU227943 & GU228139 \\
\hline C. aotearoa & CBS $128538^{*}$ & JX010205 & JX010005 & JX009564 & JX010420 \\
\hline C. arxii & CBS $132511^{*}$ & NR132055 & KF687843 & KF687802 & KF687881 \\
\hline C. australe & CBS $128540^{*}$ & JQ948455 & JQ948786 & JQ949776 & JQ950106 \\
\hline C. beeveri & CBS $128541^{*}$ & JQ005171 & JQ005258 & JQ005519 & JQ005605 \\
\hline C. bidentis & CBS $128542^{*}$ & KF178481 & KF178506 & KF178578 & KF178602 \\
\hline C. bletillum & CBS $128543^{*}$ & JX625178 & KC843506 & KC843542 & JX625207 \\
\hline C. boninense & CBS $123755^{*}$ & JQ005153 & JQ005240 & JQ005501 & JQ005588 \\
\hline C. brasiliense & CBS $128545^{*}$ & JQ005235 & JQ005322 & JQ005583 & JQ005669 \\
\hline C. brassicola & CBS $128546^{*}$ & JQ005172 & JQ005259 & JQ005520 & JQ005606 \\
\hline C. brevisporum & CBS $128547^{*}$ & JQ247623 & JQ247599 & JQ247647 & JQ247635 \\
\hline C. camelliae & ICMP 10643 & JX010224 & JX009908 & JX009540 & JX010436 \\
\hline C. camelliae-japonicae & CGMCC3.18117* & KX853165 & KX893583 & KX893575 & KX893579 \\
\hline C. caudasporum & CGMCC $3.15106^{*}$ & JX625162 & KC843512 & KC843526 & JX625190 \\
\hline C. cereale & CBS 129663 & JQ005774 & - & JQ005837 & JQ005858 \\
\hline C. chlorophyti & IMI 103806* & GU227894 & GU228286 & GU227992 & GU228188 \\
\hline C. chrysanthemi & IMI 364540 & JQ948273 & JQ948603 & JQ949594 & JQ949924 \\
\hline C. citricola & SXC $151^{*}$ & KC293576 & KC293736 & KC293616 & KC293656 \\
\hline C. clidemiae & ICMP $18658^{*}$ & JX010265 & JX009989 & JX009537 & JX010438 \\
\hline C. cliviae & CBS $125375^{*}$ & JX519223 & GQ856756 & JX519240 & JX519249 \\
\hline C. coccodes & CBS 369.75 & JQ005775 & HM171673 & JQ005838 & JQ005859 \\
\hline C. colombiense & CBS $129818^{*}$ & JQ005174 & JQ005261 & JQ005522 & JQ005608 \\
\hline C. cordylinicola & ICMP $18579^{*}$ & JX010226 & JX009975 & HM470234 & JX010440 \\
\hline C. curcumae & IMI 288937* & GU227893 & GU228285 & GU227991 & GU228187 \\
\hline C. cymbidiicola & IMI $347923^{*}$ & JQ005166 & JQ005253 & JQ005514 & JQ005600 \\
\hline C. dematium & CBS $125.25^{*}$ & GU227819 & GU228211 & GU227917 & GU228113 \\
\hline C. dracaenophilum & CBS 118199* & JX519222 & - & JX519238 & JX519247 \\
\hline C. echinochloae & MAFF $511473^{*}$ & AB439811 & - & - & - \\
\hline C. eleusines & MAFF 511155* & JX519218 & - & JX519234 & JX519243 \\
\hline C. endophytum & CGMCC $3.15108^{*}$ & JX625177 & KC843521 & KC843533 & JX625206 \\
\hline C. eremochloae & CBS 129661* & CBS 129661 & - & JX519236 & JX519245 \\
\hline C. excelsum-altitudum & CGMCC $3.15130^{*}$ & HM751815 & KC843502 & KC843548 & JX625211 \\
\hline C. falcatum & CBS 147945* & JQ005772 & - & JQ005835 & JQ005856 \\
\hline C. fioriniae & CBS $128517^{*}$ & JQ948292 & JQ948622 & JQ949613 & JQ949943 \\
\hline C. fructi & CBS $346.37^{*}$ & GU227844 & GU228236 & GU227942 & GU228138 \\
\hline C. fructicola & ICMP $18581^{*}$ & JX010165 & JX010033 & FJ907426 & JX010405 \\
\hline C. fructivorum & Coll1414* & JX145145 & - & - & JX145196 \\
\hline C. fusiforme & MFLU 130291* & NR138010 & KT290255 & KT290251 & KT290256 \\
\hline
\end{tabular}




\begin{tabular}{|c|c|c|c|c|c|}
\hline \multirow{2}{*}{ Species } & \multirow{2}{*}{ Isolate $^{\mathrm{a}}$} & \multicolumn{4}{|c|}{ GenBank accession number } \\
\hline & & ITS & GAPDH & ACT & ß-tubulin \\
\hline C. gigasporum & MUCL 44947* & AM982797 & - & - & FN557442 \\
\hline C. godetiae & CBS 133.44* & JQ948402 & JQ948733 & JQ949723 & JQ950053 \\
\hline C. graminicola & CBS $130836^{*}$ & JQ005767 & & JQ005830 & JQ005851 \\
\hline C. grevilleae & CBS 132879* & KC297078 & KC297010 & KC296941 & KC297102 \\
\hline C. guizhouensis & CGMCC $3.15112^{*}$ & JX625158 & KC843507 & KC843536 & JX625185 \\
\hline C. hanaui & MAFF 305404* & JX519217 & - & - & JX519242 \\
\hline C. henanense & LF $238^{*}$ & KJ955109 & KJ954810 & - & KJ955257 \\
\hline C. hippeastri & CBS $125376^{*}$ & JQ005231 & JQ005318 & JQ005579 & JQ005665 \\
\hline C. hemerocallidis & $\mathrm{CDLG}^{*}$ & JQ400005 & JQ400012 & JQ399991 & JQ400019 \\
\hline C. horii & ICMP 10492 & GQ329690 & GQ329681 & JX009438 & JX010450 \\
\hline C. incanum & ATCC $64682^{*}$ & KC110789 & KC110807 & KC110825 & KC110816 \\
\hline C. jasminigenum & MFU 10-0273* & HM131513 & HM131499 & HM131508 & HM153770 \\
\hline C. jiangxiense & LF $488^{*}$ & KJ955149 & KJ954850 & KJ954427 & - \\
\hline C. kahawae & ICMP $17816^{*}$ & JX010231 & JX010012 & JX009452 & JX010444 \\
\hline C. kartsii & CORCG $6^{*}$ & HM585409 & HM585391 & HM581995 & HM585428 \\
\hline C. laticiphilum & CBS 112989* & JQ948289 & JQ948619 & JQ949610 & JQ949940 \\
\hline C. lilii & CBS 109214 & GU227810 & GU228202 & GU227908 & GU228104 \\
\hline C. lindemuthianum & CBS $144.31^{*}$ & JQ005779 & JX546712 & JQ005842 & JQ005863 \\
\hline C. linicola & CBS 172.51 & JQ005765 & - & JQ949476 & JQ949806 \\
\hline C. liriopes & CBS 119444* & GU227804 & GU228196 & GU227902 & GU228098 \\
\hline C. magnisporum & CBS 398.84 & KF687718 & KF687842 & KF687803 & KF687882 \\
\hline C. malvarum & CBS 527.97* & KF178480 & KF178504 & KF178577 & KF178601 \\
\hline C. menispermi & MFLU 14-0625* & KU242357 & KU242356 & KU242353 & KU242354 \\
\hline C. miscanthi & MAFF 510857* & JX519221 & - & JX519237 & JX519246 \\
\hline C. musae & ICMP 19119* & JX010146 & JX010050 & JX009433 & HQ596280 \\
\hline C. navitas & CBS $125086^{*}$ & JQ005769 & - & JQ005832 & JQ005853 \\
\hline C. nicholsonii & MAFF 511115* & JQ005770 & - & JQ005833 & JQ005854 \\
\hline C. novae-zelandiae & CBS $128505^{*}$ & JQ005228 & JQ005315 & JQ005576 & JQ005662 \\
\hline C. nupharicola & ICMP 18187* & JX010187 & JX009972 & JX009437 & JX010398 \\
\hline C. ochraceae & CGMCC $3.15104^{*}$ & JX625156 & KC843513 & KC843527 & JX625183 \\
\hline C. oncidii & CBS 129828* & JQ005169 & JQ005256 & JQ005517 & JQ005603 \\
\hline C. orchidophilum & CBS $632.80^{*}$ & JQ948151 & JQ948481 & JQ949472 & JQ949802 \\
\hline C. parsonsiae & CBS $128525^{*}$ & JQ005233 & JQ005320 & JQ005581 & JQ005667 \\
\hline C. paspali & MAFF $305403^{*}$ & JX519219 & - & JX519235 & JX519244 \\
\hline C. petchii & CBS 378.94* & JQ005223 & JQ005310 & JQ005571 & JQ005657 \\
\hline C. phaseolorum & CBS 157.36 & GU227896 & GU228288 & GU227994 & GU228190 \\
\hline C. phyllanthi & CBS $175.67^{*}$ & JQ005221 & JQ005308 & JQ005569 & JQ005655 \\
\hline C. pseudoacutatum & CBS 436.77* & JQ948480 & JQ948811 & JQ949801 & JQ950131 \\
\hline C. pseudomajus & CBS $571.88^{*}$ & NR132059 & KF687826 & KF687801 & KF687883 \\
\hline C. psidii & ICMP 19120 & JX010219 & JX009967 & JX009515 & JX010443 \\
\hline C. radicis & CBS 529.93* & NR132057 & KF687825 & KF687785 & KF687869 \\
\hline C. rhexiae & Coll 1026* & JX145128 & - & - & JX145179 \\
\hline C. rhombiforme & CBS $129953^{*}$ & JQ948457 & JQ948788 & JQ949778 & JQ950108 \\
\hline C. riograndense & COAD $928^{*}$ & KM655299 & KM655298 & KM655295 & KM655300 \\
\hline C. rusci & CBS 119206* & GU227818 & GU228210 & GU227916 & GU228112 \\
\hline C. salsolae & ICMP $19051^{*}$ & JX010242 & JX009916 & JX009562 & JX010403 \\
\hline C. siamense & ICMP $18578^{*}$ & JX010171 & JX009924 & FJ907423 & JX010404 \\
\hline
\end{tabular}




\begin{tabular}{|c|c|c|c|c|c|}
\hline \multirow{2}{*}{ Species } & \multirow{2}{*}{ Isolate $^{a}$} & \multicolumn{4}{|c|}{ GenBank accession number } \\
\hline & & ITS & GAPDH & ACT & ß-tubulin \\
\hline C. sichuanensis & LJTJ3 & KP748193 & KP823773 & KP823738 & KP823850 \\
\hline C. spinaciae & CBS 128.57 & GU227847 & GU228239 & GU227945 & GU228141 \\
\hline C. sublineola & CBS 131301* & JQ005771 & - & JQ005835 & JQ005855 \\
\hline C. syzygicola & DNCL 021* & KF242094 & KF242156 & KF157801 & KF254880 \\
\hline C. tanaceti & CBS $132693^{*}$ & - & JX218243 & JX218238 & JX218233 \\
\hline C. tebeestii & CBS 522.97* & KF178473 & KF178505 & KF178570 & KF178594 \\
\hline C. temperatum & Coll 883* & JX145159 & - & - & JX145211 \\
\hline C. theobromicola & ICMP 18649 & JX010294 & JX010006 & JX009444 & JX010447 \\
\hline C. $t i$ & ICMP 4832* & JX010269 & JX009952 & JX009520 & JX010442 \\
\hline C. torulosum & CBS $128544^{*}$ & JQ005164 & JQ005251 & JQ005512 & JQ005598 \\
\hline C. trichellum & CBS 217.64* & GU227812 & GU228204 & GU227910 & GU228106 \\
\hline C. trifolii & CBS $158.83^{*}$ & KF178478 & KF178502 & KF178575 & KF178599 \\
\hline C. tropicicola & BCC $38877^{*}$ & JN050240 & JN050229 & JN050218 & JN050246 \\
\hline C. trucatum & CBS 151.35 & GU227862 & GU228254 & GU227960 & GU228156 \\
\hline C. verruculosm & IMI 45525* & GU227806 & GU228198 & GU227904 & GU228100 \\
\hline C. vietnamense & CBS 125478* & KF687721 & KF687832 & KF687792 & KF687877 \\
\hline C. viniferum & GZAAS $5.08601^{*}$ & JN412804 & JN412798 & JN412795 & JN412813 \\
\hline C. $\$ 1 \times$ anthorrhoeae & ICMP 17903* & JX010261 & JX009927 & JX009478 & JX010448 \\
\hline C. yunnanense & $\begin{array}{c}\text { CGMCC } \\
\text { AS3.9167* }\end{array}$ & EF369490 & - & JX519239 & JX519248 \\
\hline $\begin{array}{l}\text { Australiasca } \\
\text { queenslandica }\end{array}$ & BRIP 24607 & HM237327 & - & - & - \\
\hline $\begin{array}{l}\text { Monilochaetes } \\
\text { guadalcanalensis }\end{array}$ & CBS 346.76 & GU180625 & - & - & - \\
\hline Monilochaetes infuscans & CBS 869.96 & JQ005780 & JX546612 & JQ005843 & JQ005864 \\
\hline
\end{tabular}

asolates marked with “*” are extype or ex-epitype strains. 


\section{Appendix B}

Fungal isolates and sequences of region/genes in this study.

\begin{tabular}{lccccc}
\hline \multirow{2}{*}{ Species } & \multirow{2}{*}{ Isolate } & \multicolumn{4}{c}{ GenBank accession number } \\
\cline { 2 - 6 } C. boninense & MFLU 14-0124 & MG792809 & MK165700 & - & MH-tubulin \\
& MFLU 14-0086 & MG792816 & MH673668 & MH376390 & MH351281 \\
& MFLU 14-0261 & MG792815 & MK165703 & MH376400 & MH351292 \\
C. cariniferi & MFLU 14-0100 & MF448521 & - & - & MH351274 \\
C. chiangraiense & MFLU 14-0119 & MF448522 & - & MH376383 & MH351275 \\
C. citricola & MFLU 14-0129 & MG792821 & MK165697 & MH376395 & MH351287 \\
& MFLU 14-0131 & MG792822 & MK165696 & MH376396 & MH351288 \\
C. doitungense & MFLU 14-0128 & MF448524 & MH049480 & MH376385 & MH351277 \\
C. fructicola & MFLU 14-0087 & MG792812 & MK165691 & MH376391 & MH351282 \\
& MFLU 14-0262 & MG792814 & MK165698 & MH376401 & MH351293 \\
& MFLU 14-0148 & MG792813 & MK165701 & MH376397 & MH351289 \\
C. jiangxiense & MFLU 14-0091 & MG792806 & MH673669 & MH376392 & MH351283 \\
& MFLU 14-0092 & MG792807 & MH673670 & MH376393 & MH351284 \\
C. orchidophilum & MFLU 14-0161 & MG792818 & MK165702 & MH376398 & MH351290 \\
& MFLU 14-0162 & MG792819 & MK165704 & MH376399 & MH351291 \\
C. parallelophorum & MFLU 14-0085 & MF448525 & MK165695 & - & MH351280 \\
& MFLU 14-0077 & MG792808 & MK165692 & MH376387 & MH351279 \\
& MFLU 14-0079 & MG792820 & MK165693 & MH376388 & - \\
& MFLU 14-0082 & MG792810 & MK165694 & MH376389 & - \\
& MFLU 14-0083 & MG792811 & MH049478 & MH376386 & MH351278 \\
& MFLU 14-0120 & MG792817 & MK165699 & MH376394 & MH351285 \\
C. sp. indet. & MFLU 14-0123 & MF448523 & MH049479 & MH376384 & MH351276 \\
\hline
\end{tabular}

